\title{
COVID-I 9 Pandemic: Between Public Space and Users' Behaviours. Case studies from Egypt, Jordan, and Germany
}

\author{
Hassan Elmouelhi, Sara Nowar \\ hassan_mouelhi@hotmail.com | \\ nowar.sara@gmail.com \\ Hellen Aziz \\ Technical University of Berlin, Germany \\ Aziz.I@campus.tu-berlin.de
Ahmed M. Gaballah
Technical University of Berlin, Germany ahmedmokhtar@mail.tu-berlin.de \\ Nada Abdrabou \\ nada.samir158@gmail.com \\ Tayseer Khairy \\ Ain Shams University, Egypt \\ tayseer.khairy@gmail.com
}

\begin{abstract}
The current COVID-19 pandemic, which started in China in early 2020 and rapidly spread all over the world, has a considerable impact on people's daily lives in all its aspects, be it economic, social, and built environment. Countries have implemented different actions and set out various regulations to limit and slow down the outbreak of COVID-19. These governmental regulations ranged between semi and full lockdown as well a curfew was implemented depending on various factors; such as time and the severity of the situation. People have responded differently to those regulations depending on the measures themselves, and their culture. Nonetheless, those governmental regulations have undoubtedly affected public life and public space, residents started reclaiming their public spaces, and they have realized its importance. Some governments responded to their citizens' behaviour, which led to a better public life in the spaces, while in other cases residents have shown a level of awareness and belonging towards public space that encouraged them to initiate movements and campaigns to reclaim their space. This comparative analysis study investigates those different cases in New Cairo, Mansoura, and Hurghada in Egypt, Amman in Jordan, and Berlin in Germany and highlights the relation between the governments' regulations regarding public space and citizens' behaviour in light of the COVID-I 9 pandemic. It shows the importance of understanding the behaviours of the citizens by governments to respond accordingly.
\end{abstract}

Keywords: COVID-19, reclaiming public space, users' behaviours, governments' regulations

To cite this article:

Elmouelhi, H., Nowar, S., Hellen, A., Abdrabou, N., Gaballah, A. and Khairy, T. (202I) COVID-19 Pandemic: Between Public Space and Users' Behaviors, The Journal of Public Space, 6(I), I35-166, DOI 10.3289I/jps.v6il.1435

This article has been double blind peer reviewed and accepted for publication in The Journal of Public Space.

(c) (1) \$) This work is licensed under a Creative Commons Attribution - Non Commercial 4.0 International License https://creativecommons.org/licenses/by-nc/4.0/ 


\section{Introduction}

In early 2020, the world witnessed the spread and growth of the COVID- I 9 virus caseload, which will remain an unforgettable tragedy for the whole world that got affected severely on all levels. The World Health Organization (WHO) declared the COVID-19 outbreak as a pandemic on II March 2020, after it had been identified on 7 January 2020 in China (WHO, 2020). Countries and governments all over the world have been taking actions and regulations towards working against disseminating the virus, as the healthcare systems in countries where the pandemic was widespread were facing heavy burdens. Some of the most common measures and regulations governments adopted were restrictions on travel and transportation; which included shutting down the borders, airports, setting up strict restrictions for public transportation. Regulations also included introducing curfews to reduce mass mobility; policies regarding curfews varied depending on the severity of the situation and the government's vision. Measures concerning work-life were implemented, home-office has been introduced in many countries around the world, and people have lost their jobs, while others faced a reduction in their working hours as well as salaries. Different regulations were introduced as well in public spaces and public transportation; social and physical distancing when being in public spaces, as well as wearing masks and gloves (Aytekin, 2020). While all those measures were crucial to restrict the spread of the virus, they have shut down daily life in all its social and economic aspects. Experts in different fields have been observing those changes caused by the outbreak of COVID-19 as well as the measures and regulations set out by the governments. They have been studying and coming up with new strategies to be able to overcome those social, spatial, and economic challenges. This paper focuses on the measures set by governments concerning public spaces, and the effect of those measures on the behaviour of the dwellers. It attempts to contribute to building a better understanding of the patterns of interactions between the citizens, their use of public space, and the governmental regulations in facing the pandemic. Five case studies have been taken from three countries; New Cairo, Mansoura, Hurghada in Egypt, Amman in Jordan, and Berlin in Germany. Therefore, different measures and regulations are reviewed, as well as their effect on people and the way they responded and reclaimed their public space.

\section{Research Question: how governments' regulations could be perceived through the use of public space in different contexts?}

This paper focuses on the relationship between governments' regulations regarding public space during COVID-19, the citizens' responses to those measures, and the different behaviours in reclaiming public space. Therefore, this paper attempts to answer the following questions:

I. How have citizens responded to the regulations regarding public space set by their governments during the COVID-19 pandemic?

2. How did those responses and regulations play a role for the citizens in reclaiming their public spaces? 


\section{Research Methodology}

To answer the research questions, this paper analyses five case studies comparatively during the time of COVID-19. The case studies are New Cairo, Mansoura, Hurghada in Egypt, Amman in Jordan, and Berlin in Germany. The two MENA countries, Egypt and Jordan were chosen due to their similar neoliberal urbanism, urban challenges, in addition to their similar cultural background. That makes them interesting for comparative analysis. While Berlin's addition as a reference reflects an innovative comparative approach (Robinson, 2015) case and a good comparative example of how city management can support respecting the general rules during the pandemic. Nonetheless, the case of Berlin focused on an area where a good number of its residents are Arabs or of Arab origins, making the cultural aspect closer to the other case studies (Ayed, 2012).

A specific unified analysis has been created and followed through the research for all the cases to ensure a clear structure for the analysis and comparative analysis of the findings. This included documenting the events in a descriptive timely manner; documenting the outbreak and spread of the virus, the governmental response and measures implemented, and the citizens' socio-spatial behaviour. Three different case studies represent the Egyptian case, as each city varies in the severity of the COVID-19 situation, built environment characteristics, and demographic aspects, those aspects heavily affect the behaviour of the dwellers in reclaiming their public space. For tracing the measures taken by each government, the study relies on secondary sources (i.e., websites, official declarations, and local newspapers). To measure the citizens' responses and behaviours in reclaiming the public spaces in the studied cities -in the form of primary data- an online questionnaire was designed and shared during June and July 2020 on different social media platforms, containing a mixture of open and closeended questions. The questionnaires aimed to provide a representative sample from each studied city. it included both males and females, the majority of the sample ranging in age from 18 years old to 65 . It also included a wide range of different social and geographical backgrounds. Each city had a different number of respondents; 89 from New Cairo, 174 from Mansoura, 46 from Hurghada, 70 from Amman, and II 5 from Berlin. Informal areas settlers were not targeted in the studied cities as the investigated public spaces belong to the formal parts of the studied cities. Furthermore, the authors observed and documented the residents' spatial and social behaviours and activities in specific public spaces. Although observations are about the users with no specification of their type (age, gender), children were included as spaces' users and included as part of the families. Detailed field notes, and visual documentation, which included photographs and drawings, were of high value to this paper. The discussion of findings then presents the comparative analysis, leading to the conclusion and recommendations.

\section{COVID-I 9 Pandemic and Public Space: Literature review}

The research first explores the definitions that link the urban environment to the pandemic. According to UNESCO (2020), a public space refers to an area or place that is open and accessible to all people, regardless of gender, race, ethnicity, age, or socioeconomic level. Besides, the charter of public spaces (2015) defines the public space as "all places publicly owned or of public use, accessible and enjoyable by all for free and without a profit motive. Each public space has its own spatial, historic, environmental, 
social and economic features". We considered public gathering spaces such as plazas, squares, and parks. In this context, connecting spaces such as sidewalks and streets, are also considered as public spaces. Public open space has been defined by Jacobs (I96I) as outdoor spaces with free access for people such as cafes, retail, bazaar, parks, streets, and pedestrian paths. A collaborative framework (Innes \& Booher, 2000) in designing public spaces is a reason for their success. Thus, public open public space is successful while it becomes a conducive place for social interaction and attracts many visitors to do their activities (Danisworo, 1989; Whyte, 1985), with a wide range of activities occurring individually or in a group (Gehl, 1987, 2010).

In the context of this study, the public space becomes even more important to be studied concerning the citizens' behaviours to contribute to controlling the pandemic. Economic activities (including informal activities) take place in public spaces, as it is the main venue for urban life (Gehl, 2007). Governments have taken certain measures as a reaction to the world pandemic, known as COVID-19, according to the WHO (2020). This varies between curfews and complete lockdown in some countries, and more relaxed regulations in others. People's response regarding following those regulations also varies, which was received by the governments and local authorities either strictly or was simply ignored. Generalizing while talking about a whole country is not possible, as even within the same city some areas are strongly controlled, while other areas are not controlled regarding people's behaviours in public space (Hamzah et al., 2020). As for the urban regulations and pandemics' history between 1918 and 1919, the Spanish flu killed millions of people worldwide, it was estimated by 50 million and the urban areas had the higher mortality rates (Johnson and Mueller, 2002). The influenza vaccine would not be developed until 1945, however, the main prevention of the influenza outbreak was the quarantine (Nelson and Williams, 200I). The strategies to reduce the spread of the virus and transmission were based on reducing points of contact among infected and non-affected people through different policies like closing theatres, schools, churches, and as well as preventing large gatherings. These restrictions when implemented early lowered the peak of mortality with cumulative mortality. Also, the duration of this restriction affected; the epidemic returned with a rebound in mortality as when the restrictions relaxed (Hatchett et al., 2007).

The research methodology relies on comparative urbanism as an approach while designing the research and preparing its discussion of findings. Jan Nijman defines comparative urbanism as "The systematic study of similarity and difference among cities or urban processes." (Nijman, 2007). Comparing MENA cities with arguably similar backgrounds with a European case represented in Germany's Berlin (Neuköln, Arabs district) tests the impact of COVID-19 on public spaces throughout different urban setups (McFarlane \& Robinson, 20I2) and relying on the commonalities in the Arab culture (Ayed et al., 2012, Wari, 20I7). 'This shows how culture can play a role in the users' behaviour and attitude towards public space. This differentiation does not only portray regional differences, but it also applies to the MENA cities themselves, given the different pandemic severity and corresponding actions by governments and citizens.

\footnotetext{
' In this research's context, culture is considered the complex group of norms and values that controls behaviours, based on Clifferd Gertz's definition "a set of control mechanisms for the governing of behaviour." (Geertz, 1973, p. 14). Peterson (2004) defines culture as "the relatively stable set of inner values and beliefs generally held by groups of people, in countries or regions and the noticeable impact those values and beliefs have on the people's outward behaviours and environment" (Peterson, 2004, p. I7).
}

138 | The Journal of Public Space, 6(I), 202I| ISSN 2206-9658

City Space Architecture / UN-Habitat 


\section{Case Studies}

I Egypt

Egypt has the biggest population in the Arab region, ca. 100 million, with the highest density in the inhabited area, mainly in the Nile valley. The first case of COVID-19 discovered in Egypt was on 14 February 2020 (Gomaa, 2020), and since then Egypt has developed different restrictions to cope with the virus along three different stages. The first stage of measurements took place on 14 March; President Abdel Fattah El-Sisi issued the decision to suspend all schools and universities for two weeks to combat the spread of the virus (Egypt today, 2020). On 24 March, Prime Minister Mostafa Madbouly announced further decisions aiming to combat the spread of COVID-19 (Prime Minister, 2020). The measures were implemented with immediate effect and last until the 15th of April. These measures include the closing of Cairo International Airport, the closing of the sports clubs and the gymnasium centres, a curfew from 7:00pm until 6:00am, the suspension of all government services except for health facilities, restricted business hours during weekdays (until 1:00pm for banks, and until 5:00pm for shops and restaurants), and closure during weekends except for supermarkets and pharmacies. During this period, the government continued to apply disinfection and sterilization works on many institutions, ministries, and infrastructure facilities such as the metro, ministries offices, and departments (Hameda, 2020).

By mid-April, Egypt confirmed 2,700 cases, a week later cases had grown by more than a third. While the outbreak is just beginning, Egypt's fragile health care system is already struggling (Raghavan, 2020). The government set up further regulations during the occasions and the special vacations to control and limit the outdoor gatherings. For example, during the Coptic Easter vacation on 15 April, the government set up regulations to close all the beaches, the parks, and the Nile corniche. Moreover, during Ramadan which started on 24 April, the government decreased the curfew hours to be only from 9:00pm to 6:00am while the mosques were still closed. And during the Eid from 24 to 29 May, the government set up strict regulations to close all the shops, beaches, public transportation means, and the Nile corniche and it increased the curfew hours to start from 5:00pm (Garda World, 2020). On 23 June, the Prime Minister announced the lift of most of the restrictions and moved to coexist with the virus (Egyptian Streets, 2020a). As a result, restaurants, cafés, sports clubs, and cultural facilities such as cinemas and theatres will be allowed to reopen but are required to operate at $25 \%$ off their capacity, according to Madbouly's statement. As per the new regulations, the opening hours were extended until 10:00pm instead of 4:00pm, and people are free to move and go out without any curfew hours (Egyptian Streets, 2020b).

\section{I.I New Cairo, Egypt}

New Cairo city is one of the biggest new urban communities that has been officially established as a city through a presidential decree in 2000 , as a response to accommodate the overpopulation in Egypt. It is located on the eastern side of greater Cairo, and adjacent to the ring road. It occupies an area of about $500 \mathrm{~km} 2$ with low density in general, according to New Urban Communities Authority (NUCA), its population is around three million people. New Cairo consists of five planned settlement sections which are the Fifth Settlement, the First Settlement, the third and the eastern side, as well as the southern side with 330 new gated communities. The 
three settlements contain social housing, gated communities, and private housing (NUCA, 2020). Generally, residents lack any public green parks and usually depend on private club sports or malls for recreational time, which was heavily noticed during the pandemic and the curfew hours.

Public Social housing (distinguished housing-Al Motamayez) in the Third Settlement is the focus area for observations; it represents a housing model designated for the middle-upper middle class adopted by the government and replicated all over the country. Respondents of the questionnaire were residents of different New Cairo city areas. The unclear borders between the third and the fifth settlements made the responses from both be considered together as one category. As a result of the restrictions of COVID-19 and national regulations of working hours and physical distancing limitations, around $65 \%$ of the participants got affected either by working from home full-time or on a part-time basis. Before the pandemic, $76 \%$ of the participants used private cars for transportation, while $12.5 \%$ depended on public transportation and $2.5 \%$ used Uber or Careem. whereas during the pandemic, private car usage decreased to $63.7 \%$, and dependency on public transportation decreased to $2.5 \%$ and the dependency on private services like Uber or Careem remained the same on an of average $2.5 \%$. The reasons for going out during pandemic time were prioritized. On top, around $71 \%$ listed going out for grocery shopping, while going out for work was listed as a second priority by around $41 \%$, then $29.5 \%$ went out for walking or running. The weekly frequency for going out to work during the pandemic time was also an indicator to know to what extent people went out. Around $40 \%$ (the majority) answered they worked from home, while $23.8 \%$ went out once or twice a week. $18 \%$ answered they went out to work three to four times per week. The answers revealed that the majority respected restrictions and regulations during the pandemic time and followed restrictions over social distancing. $62 \%$ never go out to visit nor meet friends or family members.

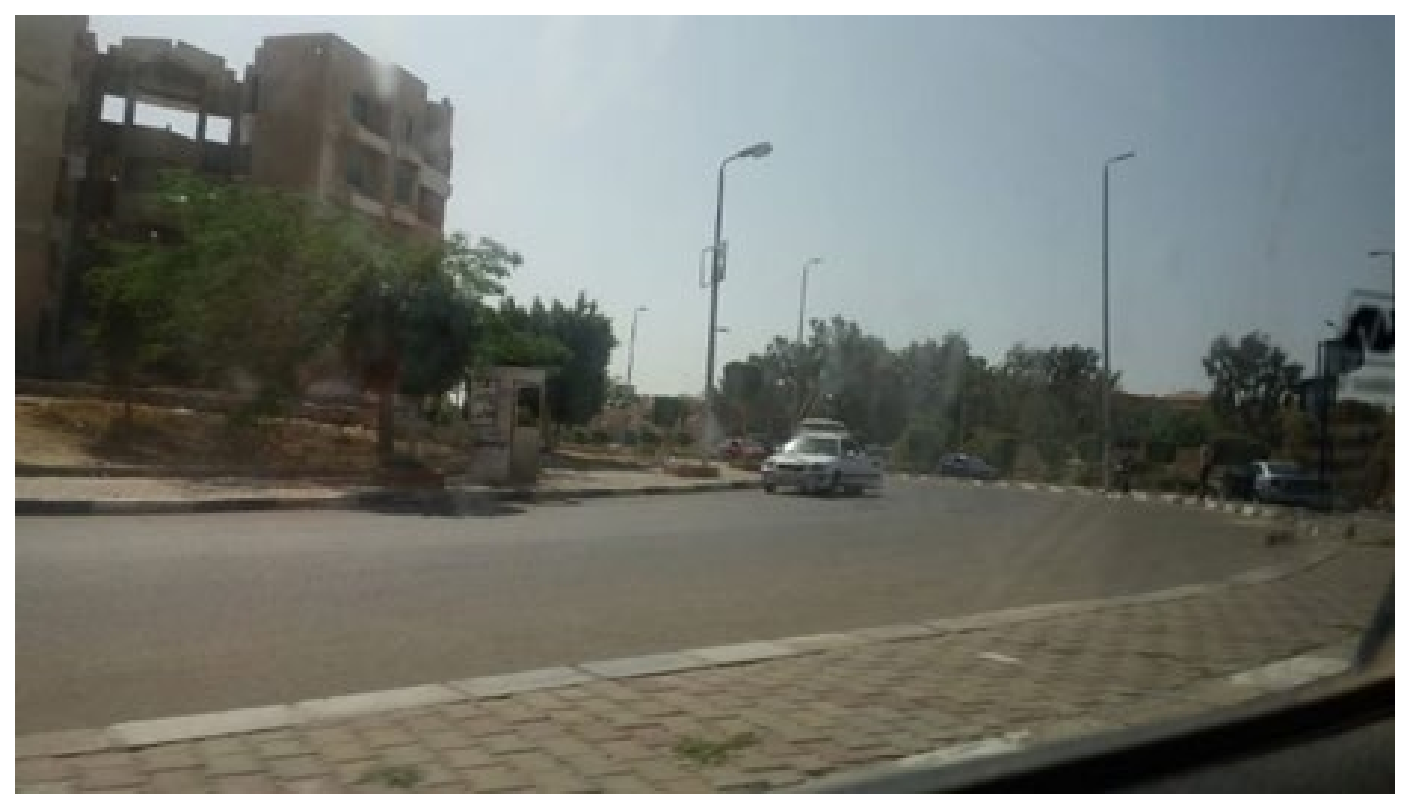

Figure I. The Third Settlement in New Cairo during the pandemic (source: Khairy, I4 April 2020). 
The usage of public space in New Cairo city was limited by choice, before the pandemic, the study showed that private clubs were the first choice with $67 \%$ and malls counted as the second choice with $52.5 \%$, while open green spaces were ranked in third place by $27 \%$. While further answers were to go out during the pandemic indicated the increasing demand of residents to use streets as public spaces by $63 \%$ as the following chart illustrates.

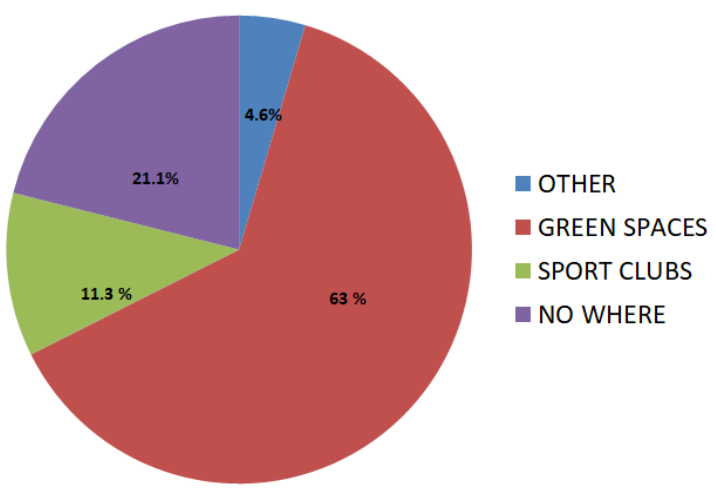

Figure 2. Residents' usage of public space during the pandemic (source: Khairy, July 2020).

Besides, during the pandemic, answers indicated their need to go for a walk in the nearby public spaces by $74 \%$, cycling $18 \%$, and running is $9 \%$. While there has been a night-time curfew imposed on 24 March, residents in the settlement broke the curfew hours especially during Ramadan ${ }^{2}$ to go for walks, cycle, and walk their pets (as shown in figure 3).

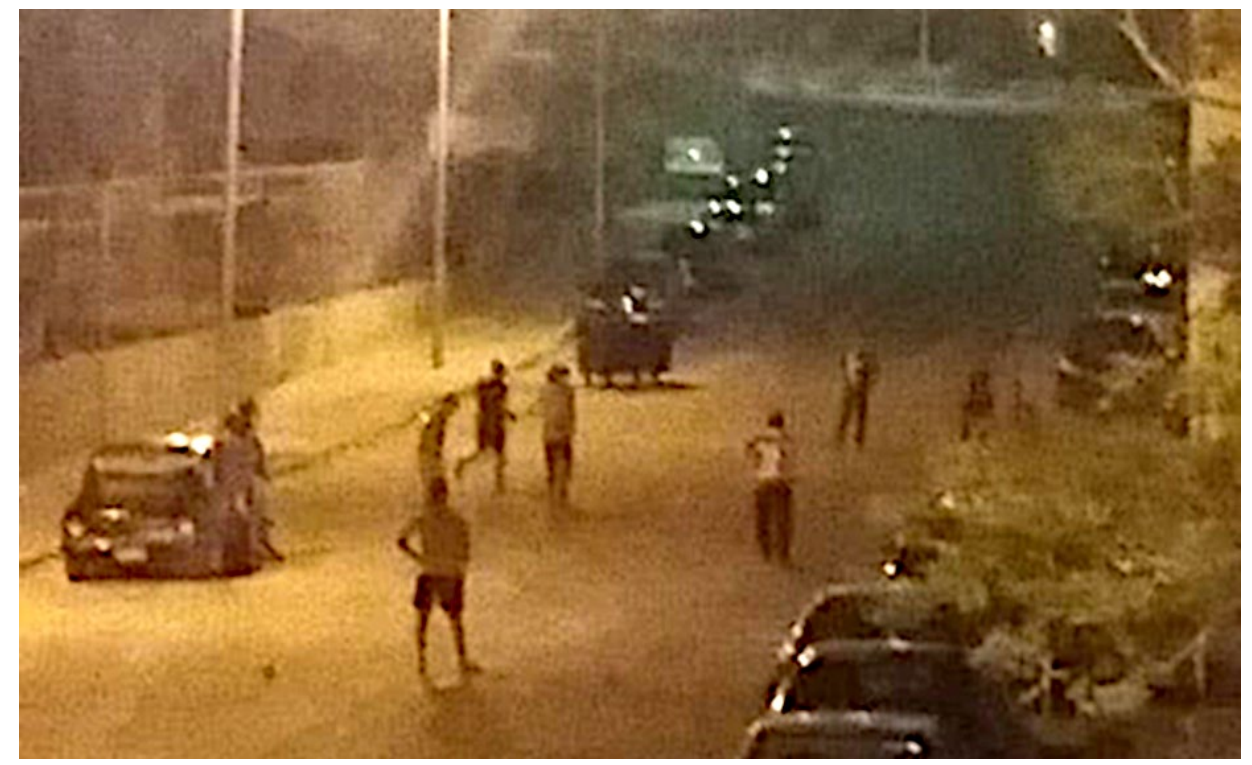

Figure 3. Residents from third settlement breaking the curfew during Ramadan (source: Khairy, 24 May 2020).

\footnotetext{
${ }^{2}$ Curfew hours during Ramadan (23rd April to May 23rd, Mosques were closed completely which is marked one of the main features during the holy month for the Muslims.
} 
With the time prolonged of curfew and lockdown, residents started to reclaim their public spaces more. They started creating safe spaces for children to play; families started to appropriate spaces in between buildings to make them child-friendly. They used recycled materials such as car tires to create playgrounds. Those spaces acted as family gathering spots as well; this is shown in figure 4. One of the participants expressed "I want to take my kids out to an open space where they can run and enjoy" (female, 30s).

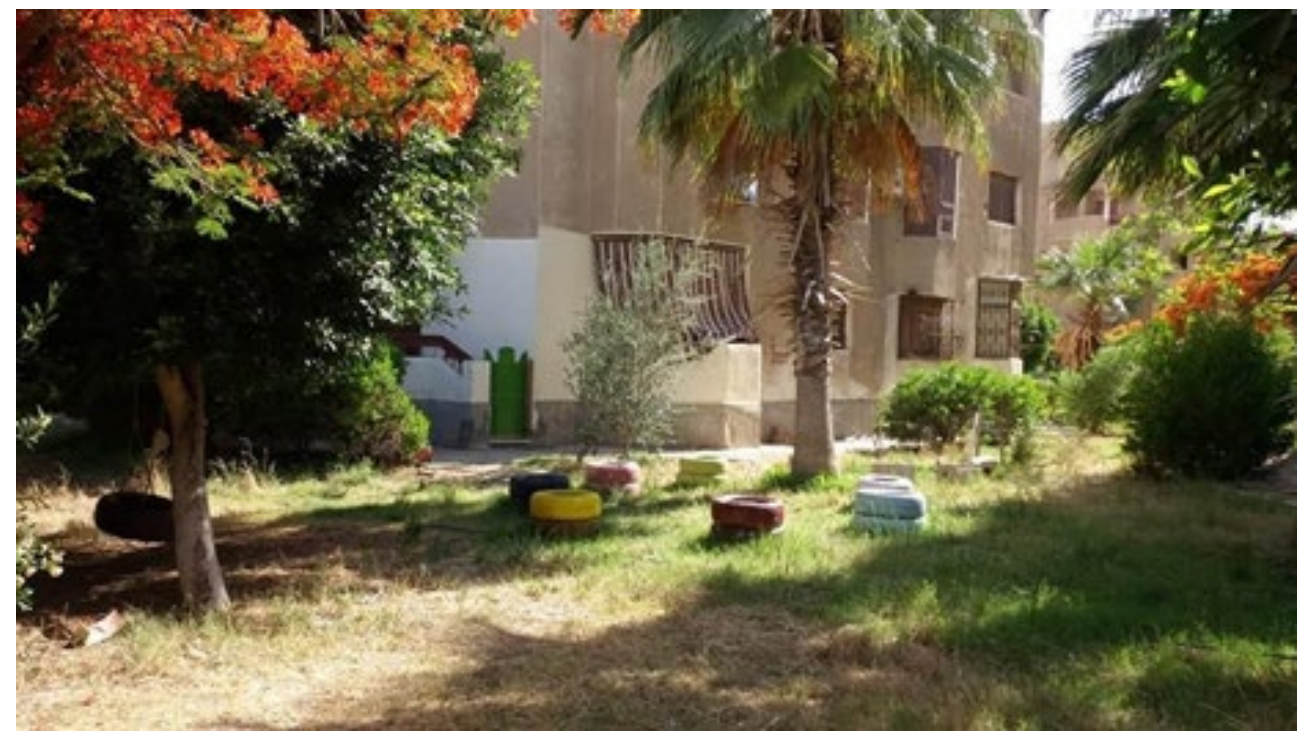

Figure 4. Interventions by residents aiming to create safe public spaces for children (source: Khairy, 3I May 2020).

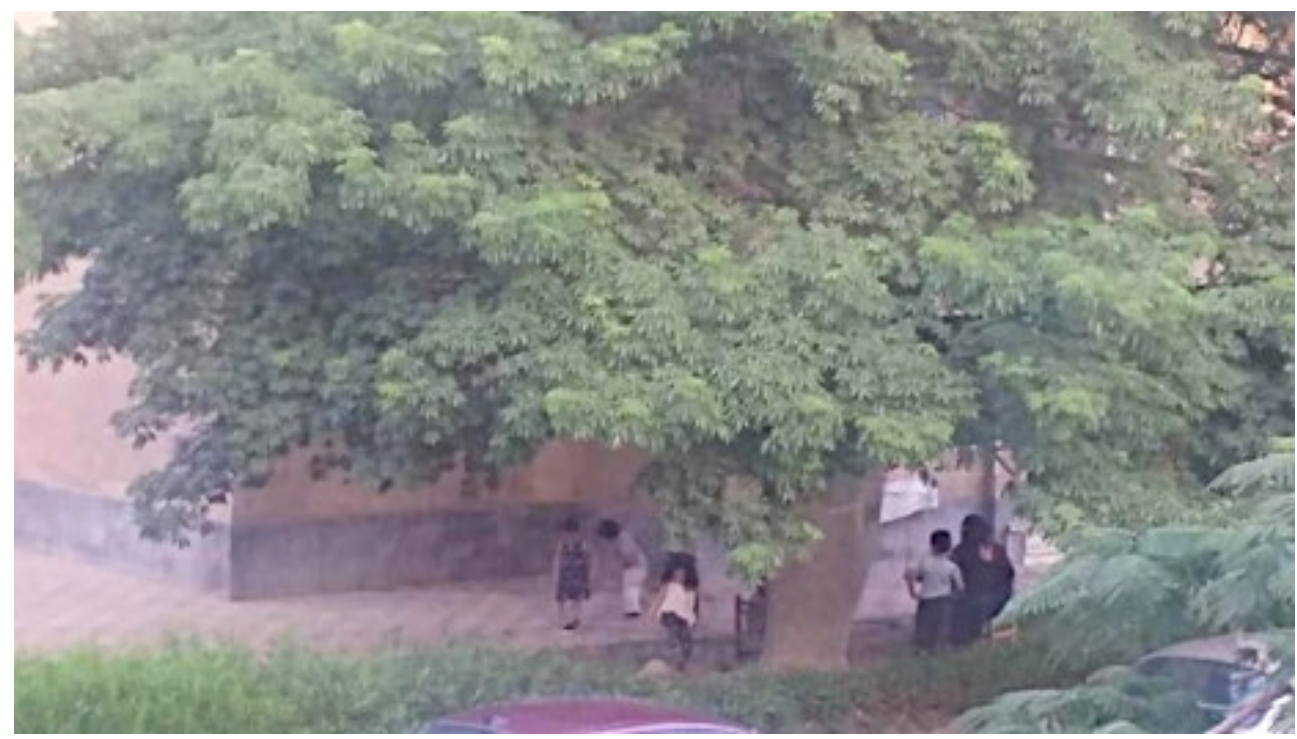

Figure 5. A mother taking her children to an in-between space while bringing chairs along (source: Khairy, 9 June 2020).

The questionnaire also surveyed the future reactions of residents after the lockdown ends by highlighting the need for going out to public green spaces. The answers revealed that $48 \%$ will use sports clubs while $40.5 \%$ will continue using the streets as their public 
spaces for walking. It can be realized that residents long for open public space, as one of them expressed; "once this is over, I want to go out to a big open space full of greenery, or a public park" (female, 30s).

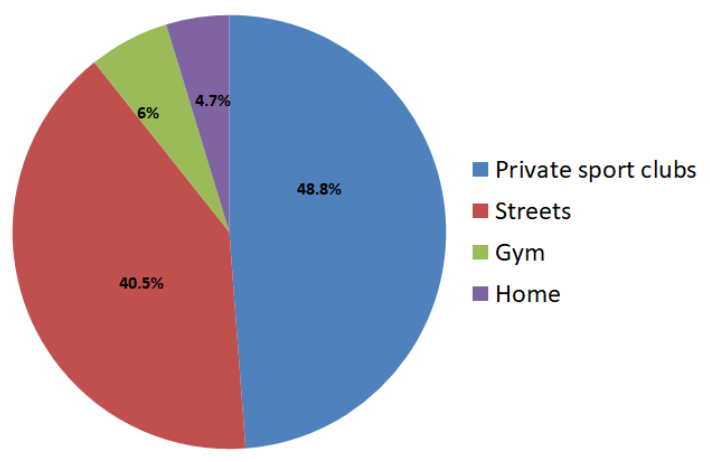

Figure 6. Public space and physical activity chart in the case of the reopening of the gym and the sports clubs (source: Khairy, July 2020).

Negative attitudes were observed during pandemic times as well, people started to throw the used masks and gloves in the streets and public spaces, as shown in figure 7. This indicates the immense need to raise awareness towards public space.

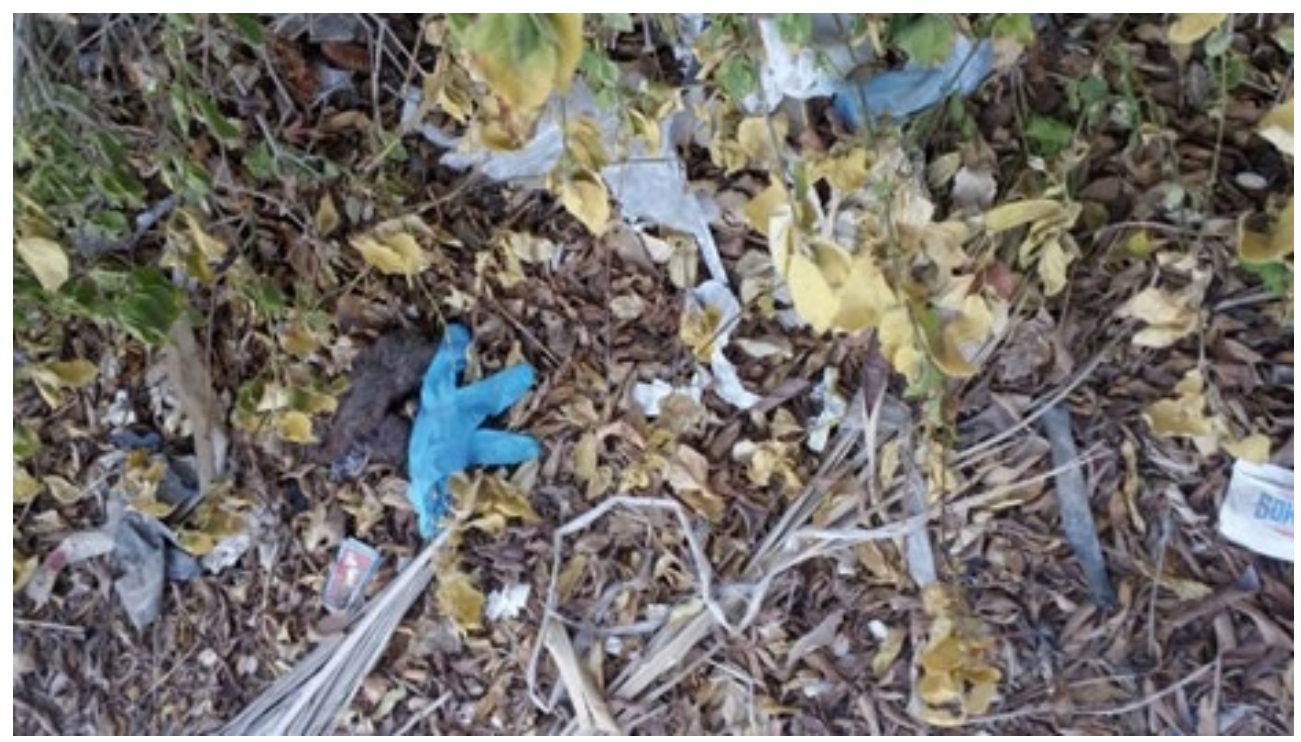

Figure 7. waste of masks and gloves in the third settlement area, new Cairo (source: Khairy, 14 June 2020).

\section{I.2 Mansoura, Dakahlia governorate, Egypt}

Mansoura city which was established in 1219 AC is located in the Nile Delta in Egypt and lies on the eastern side of the Damietta branch of the Nile. It is the capital of the Dakahlia governorate and is administratively divided into two districts: the eastern and the western districts (Dakahlia Governorate Website, 2020). The city area is about 28.2 
$\mathrm{km} 2$, with a population of 594,721 people according to the population census in 2019 (city population, 2020).

The observations in this case study focused on the Nile corniche and its extension of El Mashaya street which represents the main street in Mansoura, in addition to Kafr El Batamas street market, as an example of vital public space and the largest street market in the city.

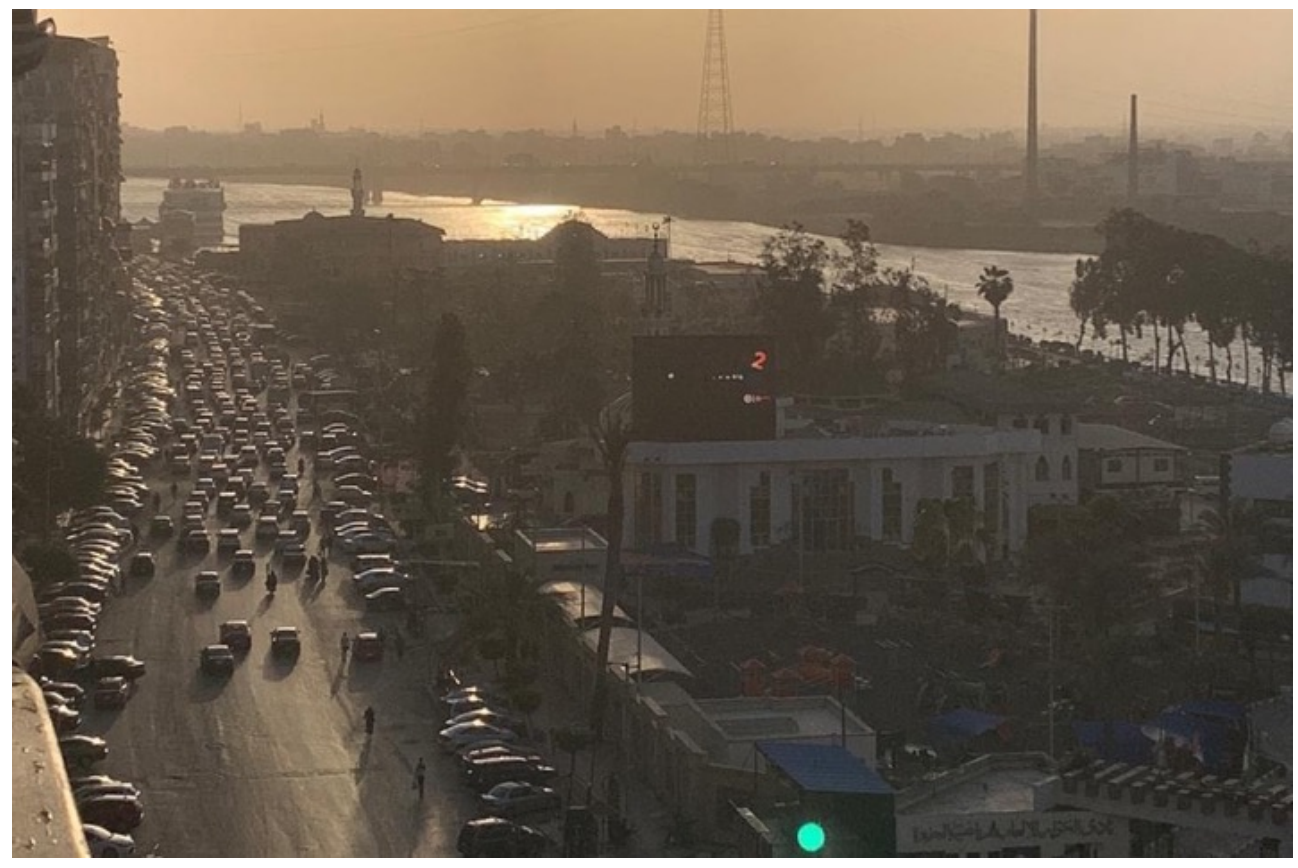

Figure 8. The crowd in El Mashaya Street (Source: Aziz, 7 April 2020).

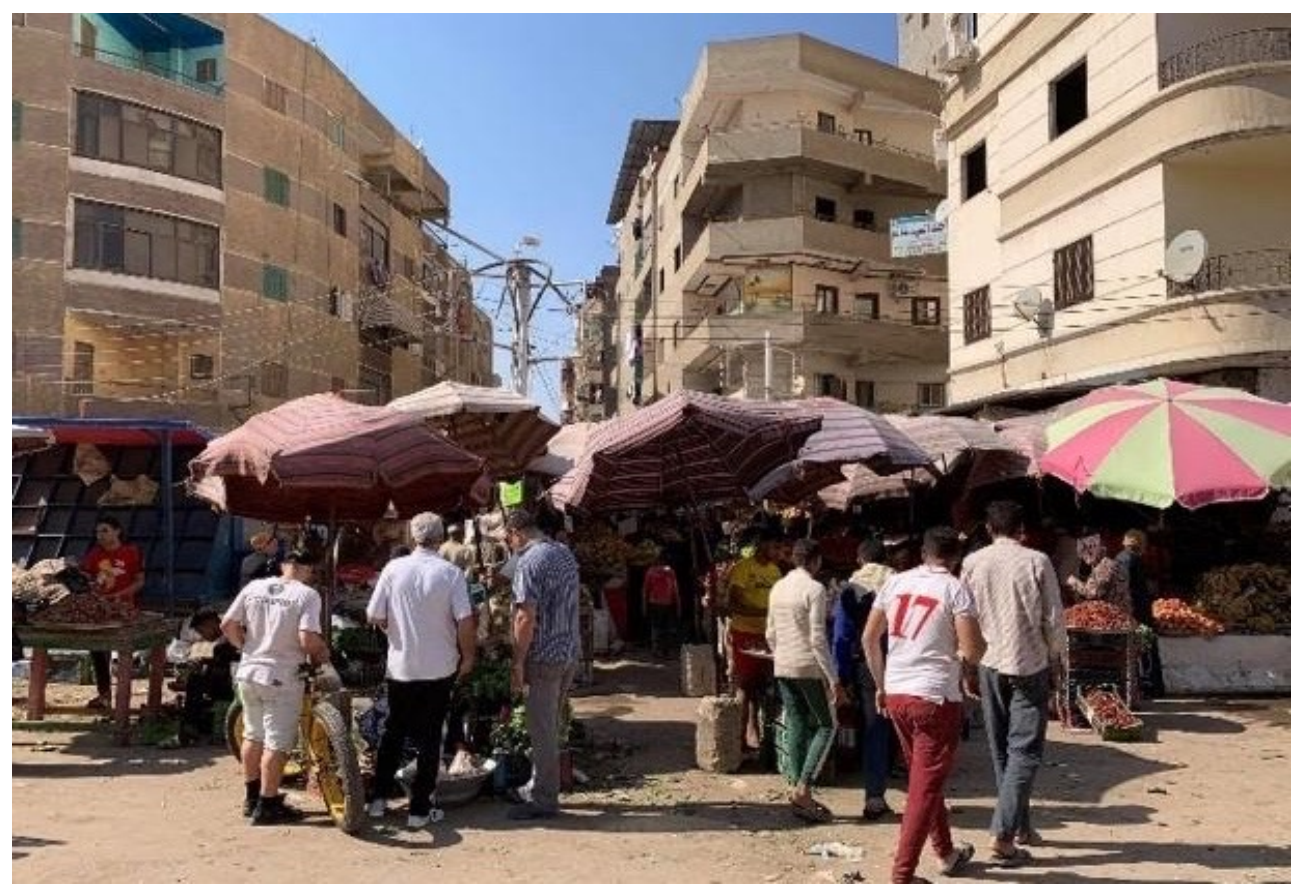

Figure 9. The crowded Kafr El Batamas street market before the curfew hours (source: Aziz, 30 April 2020) 
Despite the governmental regulations and campaigns that encouraged the people to stay at their homes and only go out for essentials to avoid the outbreak of the COVID-19 pandemic, the streets were relatively crowded in Mansoura city. Based on the questionnaire, the pandemic also affected their choice of shopping destinations, as the number of participants who preferred to go to the street markets for shopping decreased from $19 \%$ to $13 \%$. While the number of people who preferred supermarkets significantly decreased from $87 \%$ to $54 \%$. This shows that the people managed to replace using supermarkets with delivery service, meanwhile the street markets had no alternative in their point of view. Figure 9 shows the street market in Kafr El Batamas full of people.

Due to governmental regulations regarding the closure of sports clubs and gyms, $54 \%$ of the participants of the questionnaire took on walking in public spaces as the main physical activity. When asked about the most used public spaces; the participants clarified that the Nile corniche and El-Mashaya Street were their preferred options, which was confirmed through the observations. People -families, men, and womenfrom different age groups and social classes walked and ran, either during the early hours of the day or just before Iftar time in Ramadan, as shown in figure 10. Moreover, organized groups of women started to exercise in El Mashaya Street in the early morning as shown in figure $\mathrm{II}$. Women started using and reclaiming public space in ways and methods that had not existed before the pandemic.

There were other observed activities along the Nile such as flying kites, as shown in figure 12.

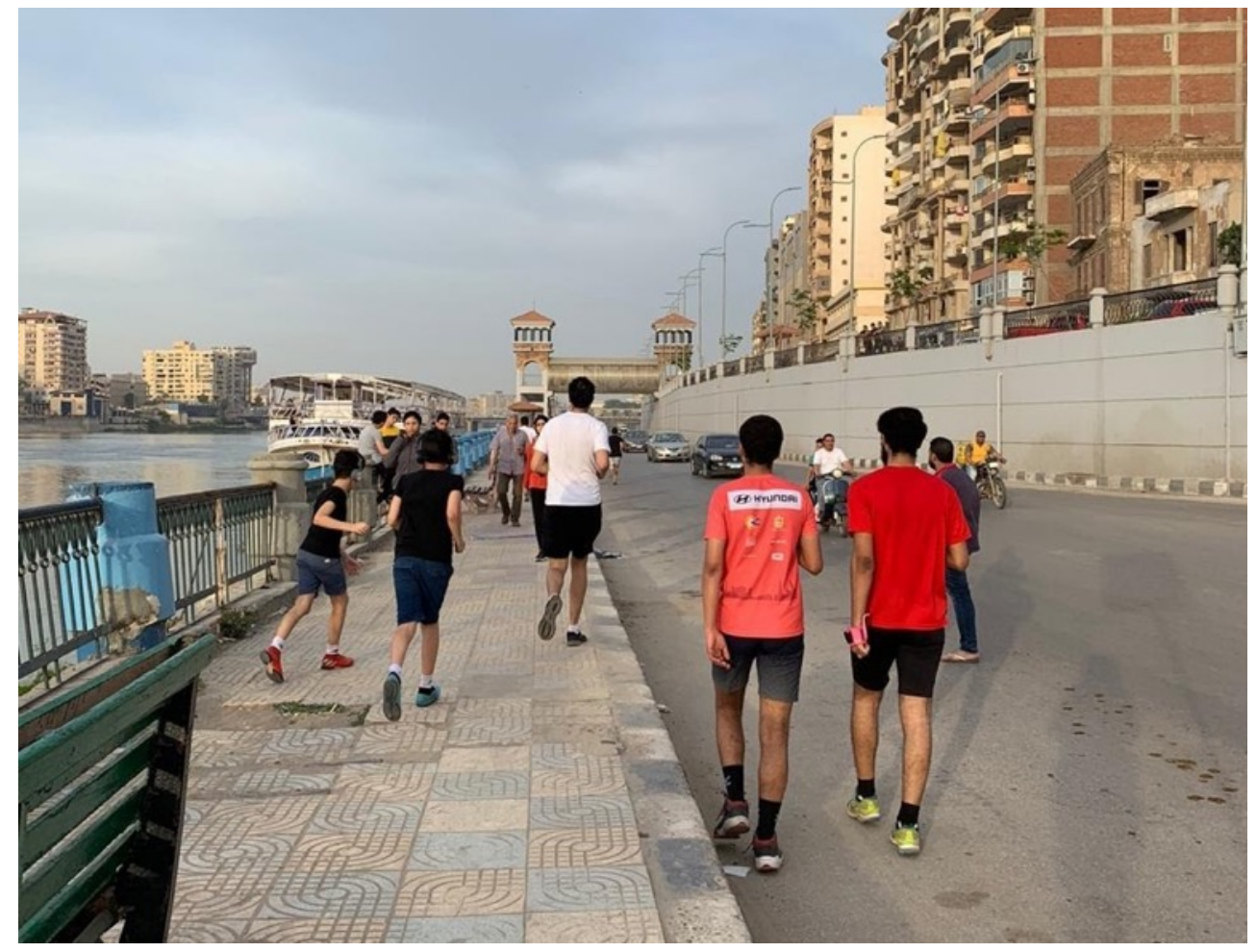

Figure 10. Using the Nile corniche as a track for walking and running before Iftar in Ramadan (source: Aziz, I5 May 2020). 
COVID-1 9 Pandemic: Between Public Space and Users' Behaviours

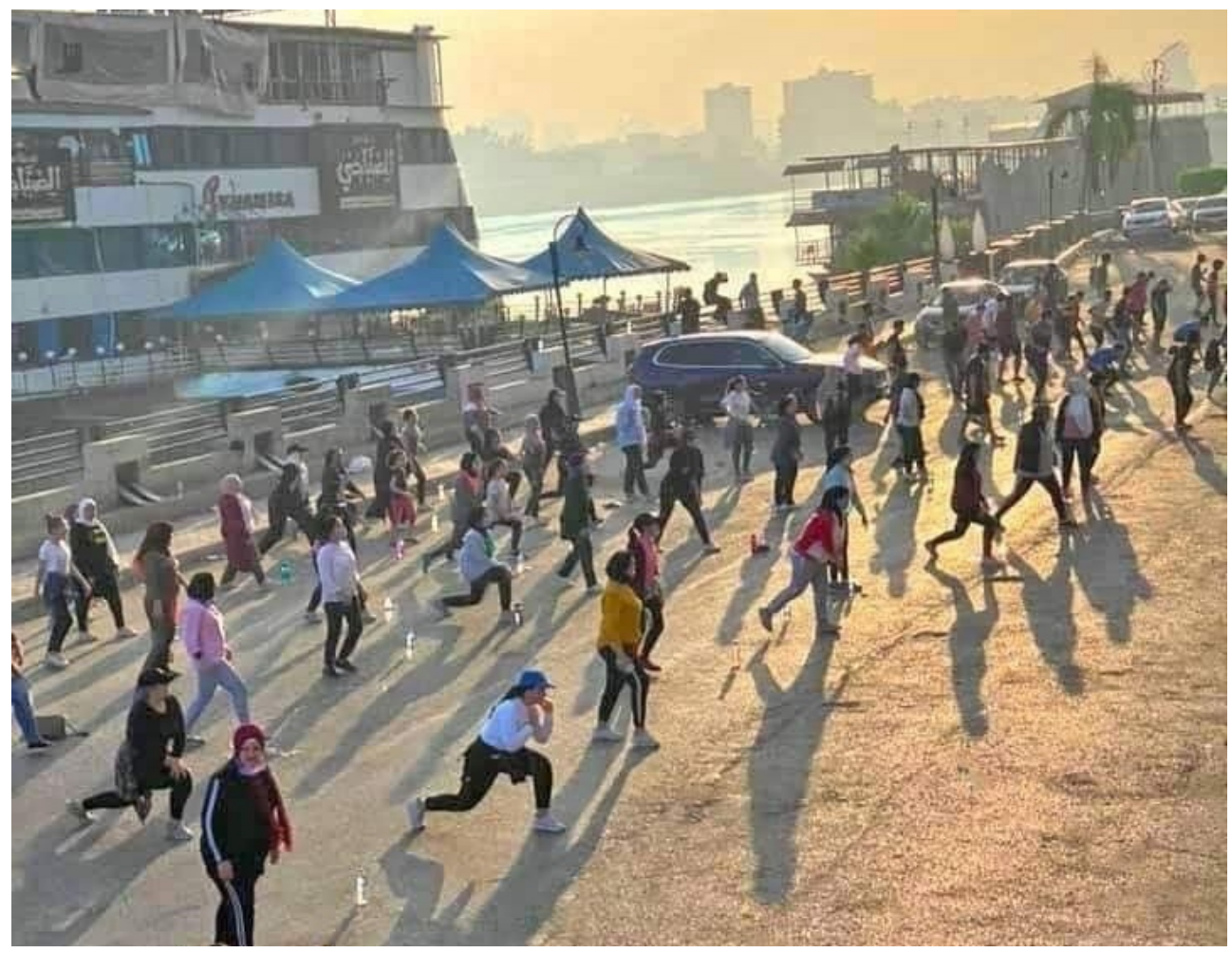

Figure II. Doing exercises in the streets and public spaces in the early morning (source: El Yom El Sabeaa, 9 July 2020).

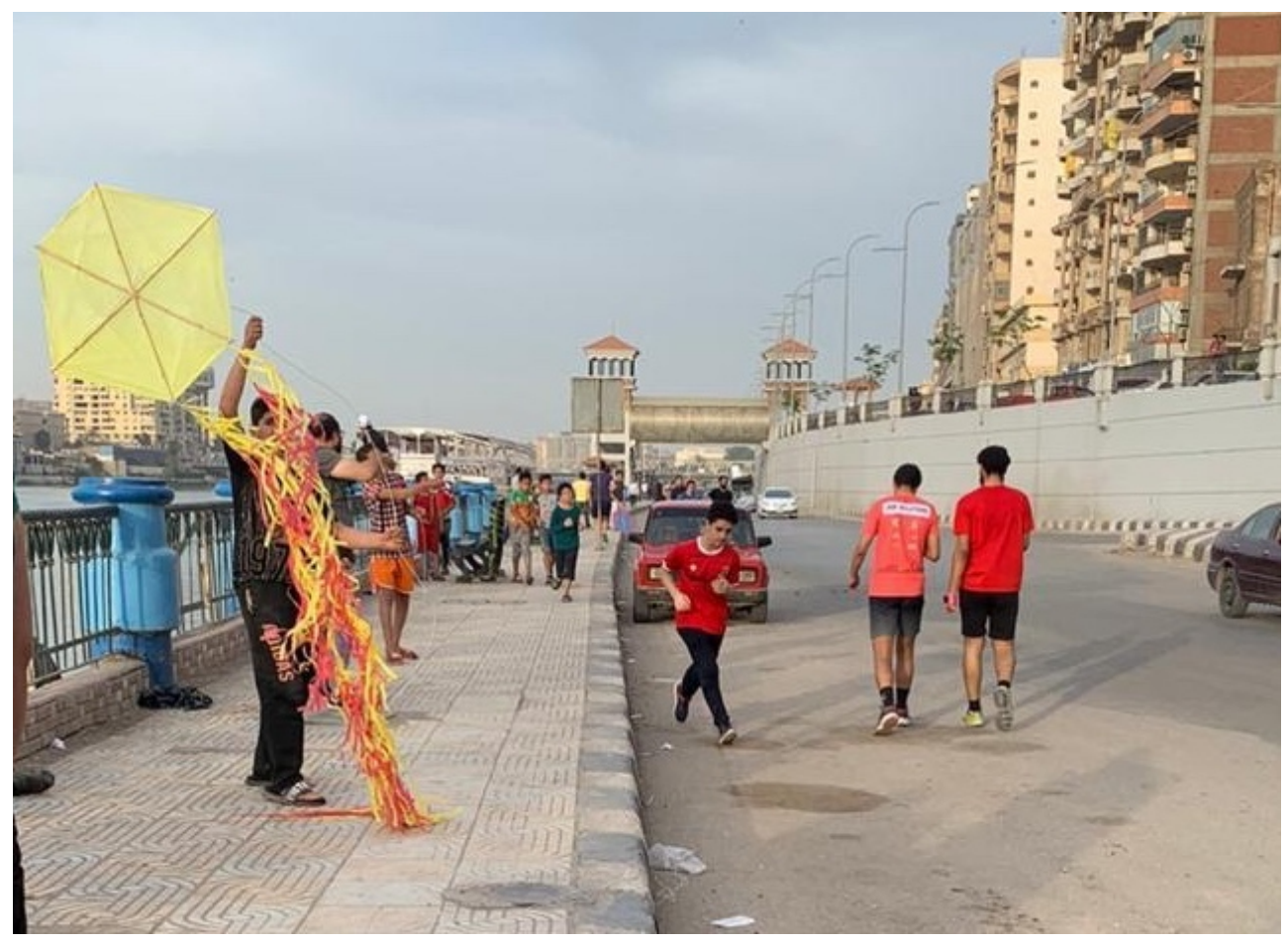

Figure 12. The activities along the Nile corniche before Iftar such as fishing and kite flying (source: Aziz, May 2020). 
Although the pandemic affected the quality of using the public space and introduced new activities to take place there, it also decreased the rate of using the public spaces as $77 \%$ of the participants mentioned. On the other hand, 15\% declared that their use of public spaces increased during the pandemic. The chart below illustrates the participants' preference for physical activities in case of reopening gyms and sports clubs, and that shows a change in the culture of using public space in Mansoura; more than $50 \%$ of the participants would still prefer to exercise in public spaces such as the Nile Corniche, streets, and public gardens.

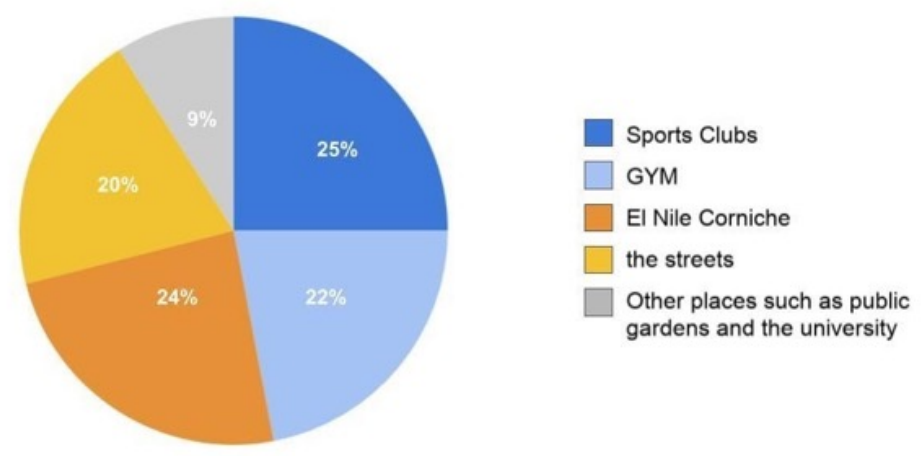

Figure 13. Public space and physical activity chart in the case of the reopening gyms and the sport clubs (source: Aziz, 2020).

\section{I.3 Hurghada, Red Sea Governorate, Egypt}

Egypt's Red Sea Governorate covers $1080 \mathrm{~km}$ of the coast along the country's eastern border on the red sea, housing a population of 380, 184 (CAPMAS, 2020). It is one of Egypt's most popular tourism destinations, given its beautiful beaches, natural reserves, and mountains. Hurghada is the Red Sea capital, with a population of 95,622 (World Population Review, 2020). Its population ranges from Egyptians to Germans, Russians, and more. Hurghada is divided into Northern and Southern districts (GOPP, 2020) stretching longitudinally across the coastline. The northern district is predominantly local Egyptian neighbourhoods and the governorate administrations' centre. The southern district is a diverse social district and is mostly the tourism centre of the city (GOPP, 2016).

As much as COVID-19 affected everyone around the world, a tourism-based city - like Hurghada- was highly affected economically and socially by such a lockdown. Since COVID-I 9 first started spreading in Egypt, the Egyptian Prime Minister and Health Minister put Hurghada in the primary tourism and city lockdown with Luxor and Aswan in March 2020, before the national curfew regulations took place (AFP, 2020).

The field observations describe the city's procedures and its residents' adaptation during curfew and lockdown from March till July on the waterfront and walkways in AlAmal, Al-Sakalla, \& Al-Dahar Neighbourhoods. Some of Hurghada's public spaces were locked such as Al-Nasr promenade in Al-Dahar (see Figure I5). Other multi-use spaces (i.e. supermarkets, services) worked until curfew such as Sherry promenade in AlSakalla (see Figure 16). Overall, the city's dwellers followed social distancing, so public spaces had very little traffic. Given the constant adaptation of curfew hours throughout 
the country, Police forces roamed around the city, to ensure that outlets are closed on time. In addition to the police forces, the streets were physically blocked during curfew hours to block motorized and non-motorized traffic.

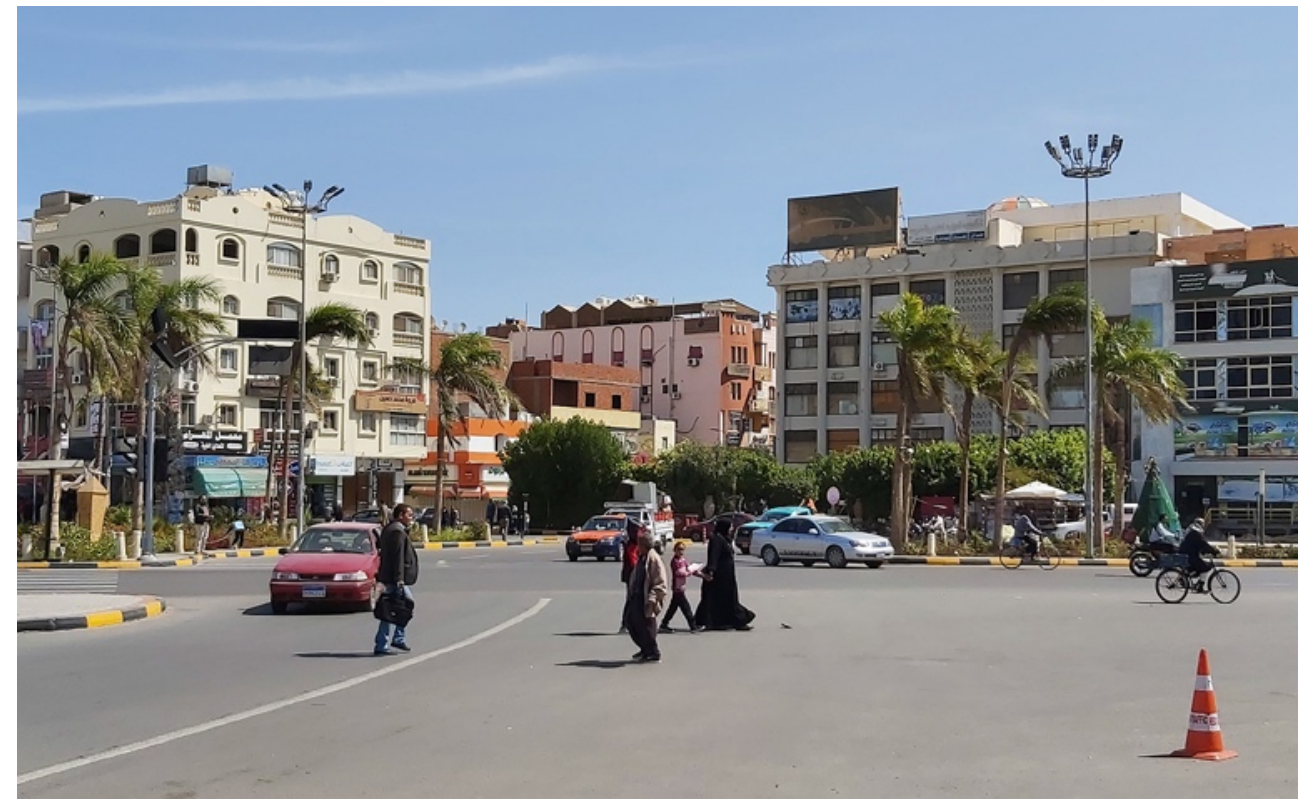

Figure 14. Everyday morning traffic (motorized and non-motorized) in the city's local center, Dahar square (source: Abdrabou, 10 March 2020).

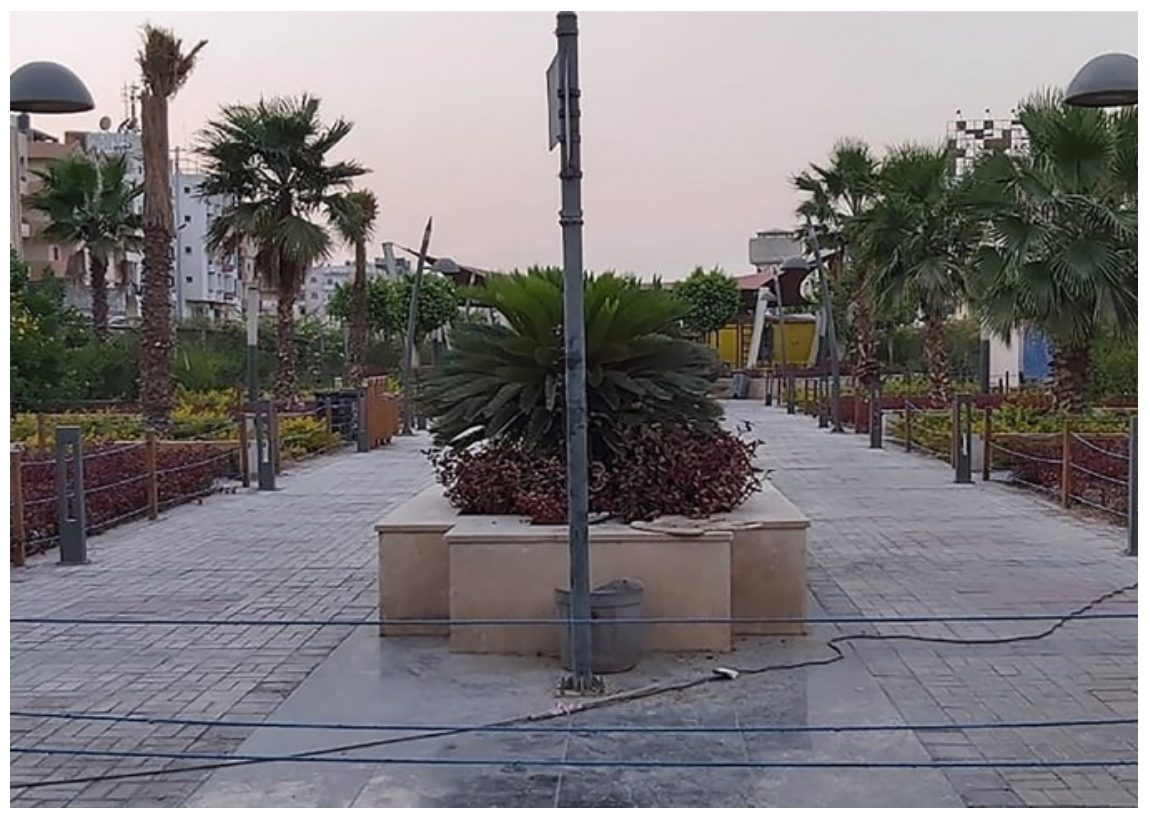

Figure 15. Banned public spaces during COVID-I9 (informally walked through by passersby), Al-Nasr Promenade, Al-Dahar, Hurghada. (source: Abdrabou, 28 July 2020). 


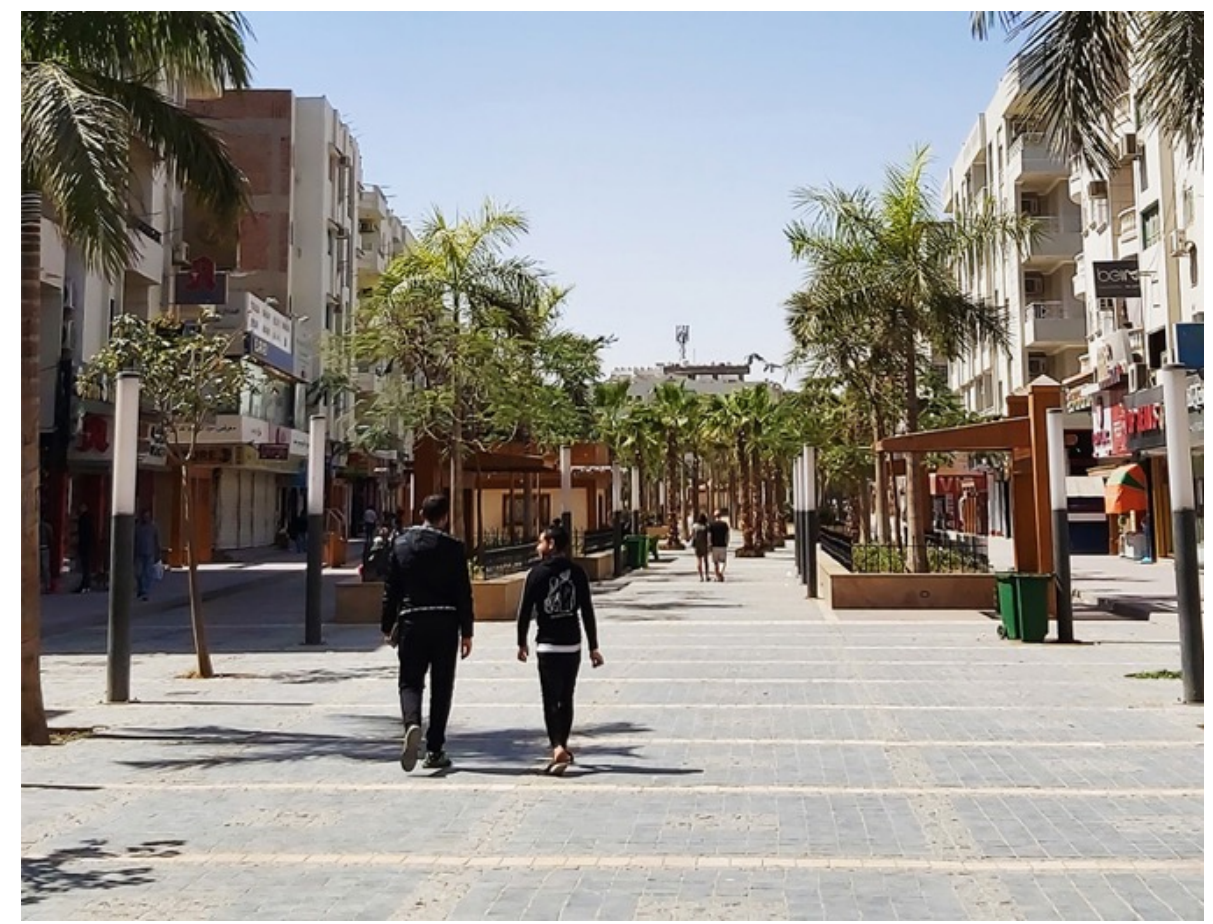

Figure 16. Functioning Multi-use Walkways, Sherry Promenade, Al-Sakalla, Hurghada. (source: Abdrabou, 10 March 2020).

Many national occasions took place during COVID-19 lockdowns such as the Coptic Easter, the Pharaonic Easter, and Ramadan. As those are outdoor gatherings feasts where Hurghada is a national vacation destination, they required further regulations by the governorate. Boat trips (private or rented) were banned, beaches and Corniche were blocked (see Figures 17 and I8) (Altayry, 2020), and trips from and to Hurghada were banned too.

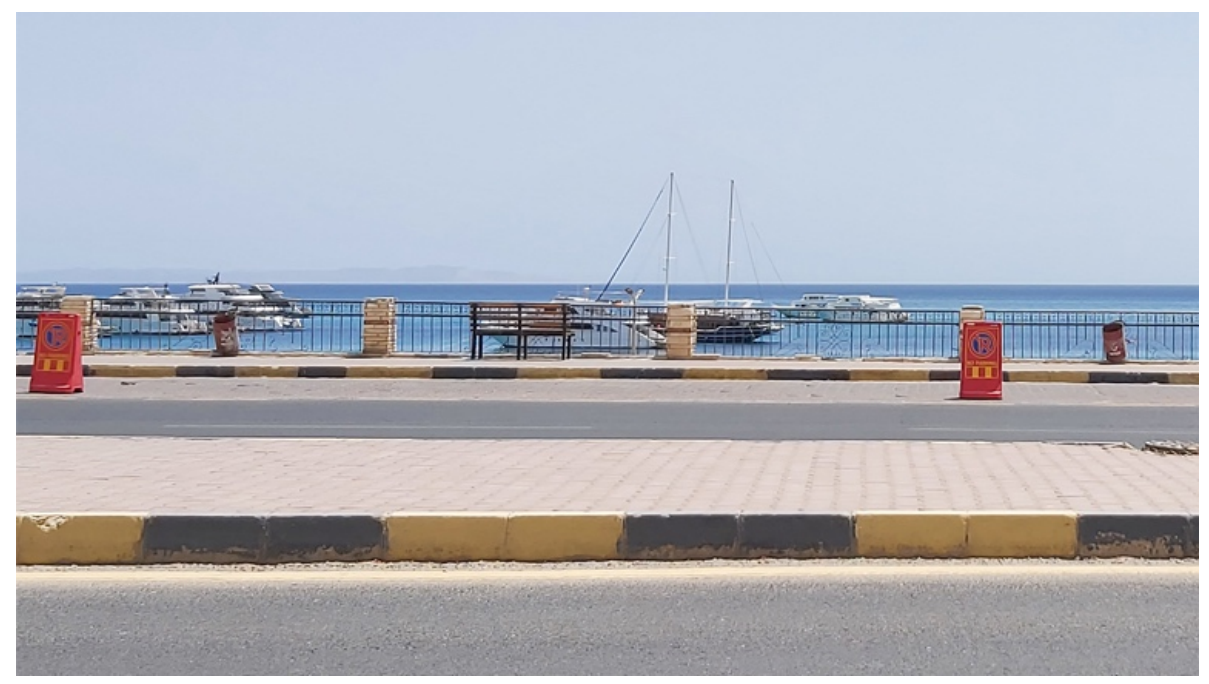

Figure 17. Corniche, Al-Amal, Hurghada (source: Abdrabou, 2 June 2020). 
COVID-19 Pandemic: Between Public Space and Users' Behaviours

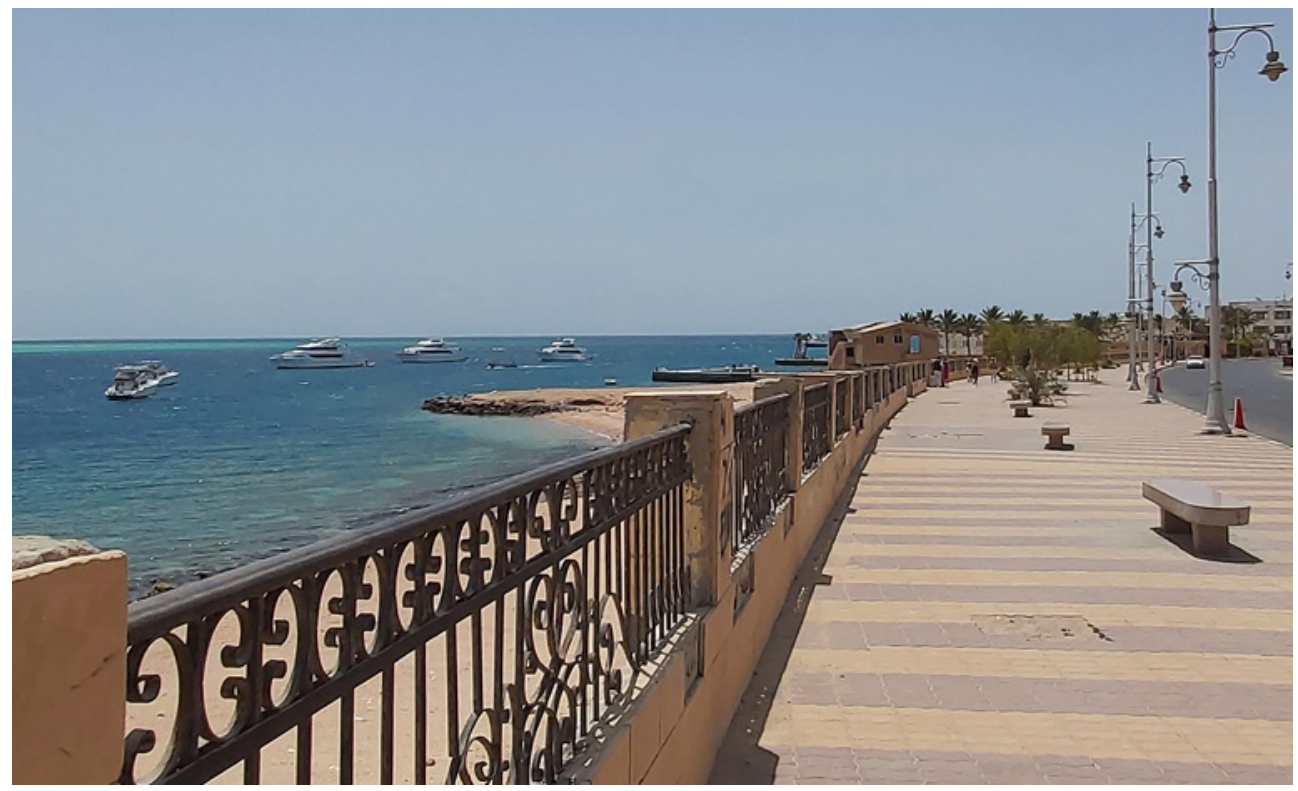

Figure 18. Corniche, Al-Hadaba, Hurghada (source: Abdrabou, 2 June 2020).

Meanwhile -based on observations- it can be argued that Hurghada's residents' adaptation to the COVID-19 regulations, such as the outlets and services' opening hours kept developing along with the curfew. More foreign residents found their way through the city using bicycles for transportation, given the emptier streets along with Hurghada's southern districts, which were mostly occupied by tourists such as Sheraton Street.

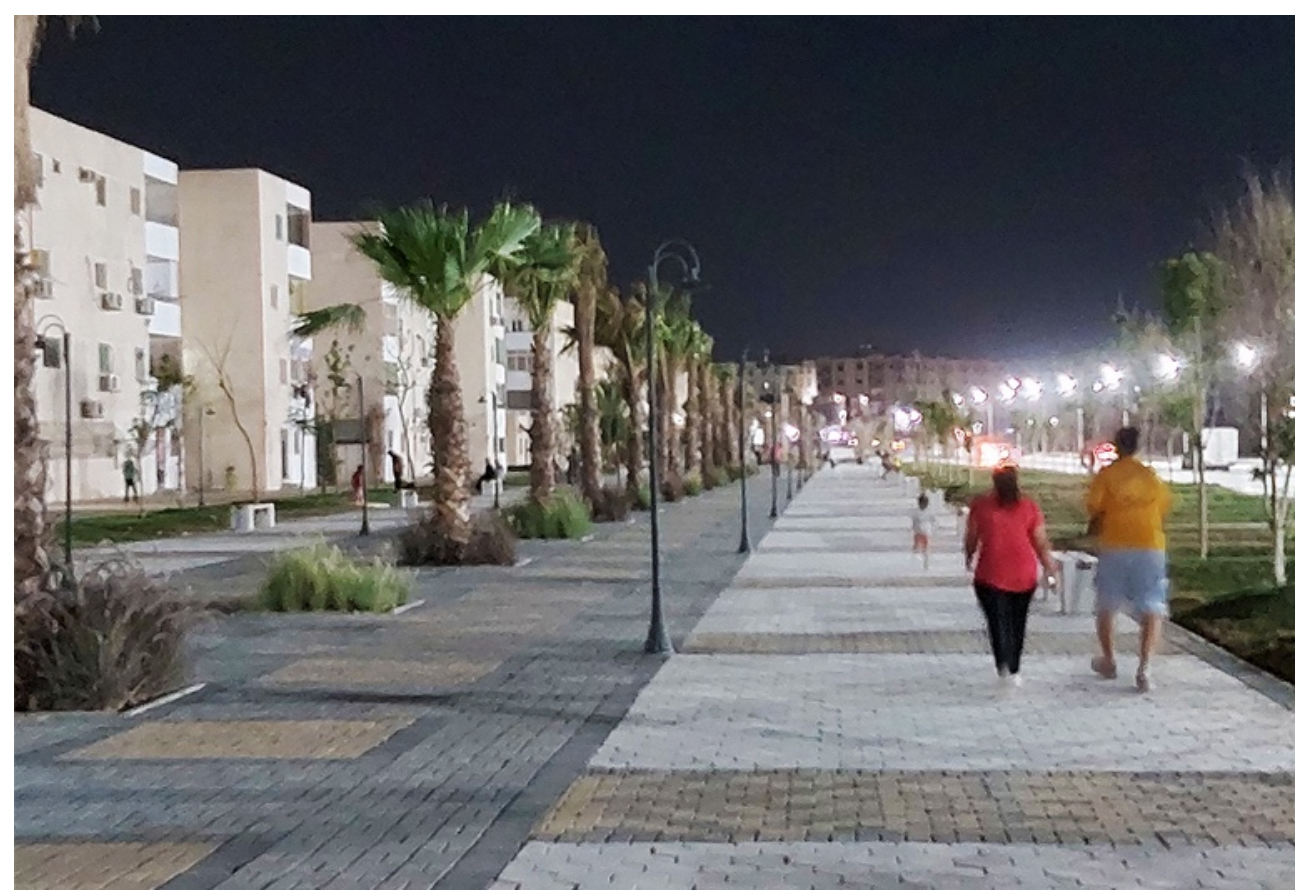

Figure 19. Families walks right before curfew, Al-Sakalla Promenade, Hurghada (source: Abdrabou, 3 June 2020). 
With no occasions or feasts, Hurghada's residents found an outlet in visiting the city's Corniche, spending time watching the sea, and enjoying the fresh breeze along Al-Amal and Al-Hadaba zones. Moreover, the little hidden openings on the beaches allowed people to take a dip into the water, since all beaches are closed, while some enjoyed their time fishing. Another outlet is a newly developed public space Al-Sakalla Promenade within a residential zone, where residents around this walkway went out before curfew hours with their families to enjoy a distant outdoor walk (Figure 19).

Throughout those restrictions and procedures, the online questionnaire investigated the social usage of the city's public spaces further. $43.9 \%$ commuted to work by their private cars, and $26.8 \%$ by public transport and $9.7 \%$ commuted via non-motorized transport before COVID-19 broke out. During the pandemic, public transport use for work commute decreased to II.9\%; and since $46 \%$ started working from home during COVID-19, 19\% did not commute to work anymore. Leaving the house for more than work during the COVID-19 pandemic shows that $76 \%$ went shopping, and $23.9 \%$ went running and walking.

Before COVID-19, about $73.3 \%$ of the respondents shopped in supermarkets, $8.8 \%$ shopped in street markets such as Al-Dahar and the Old Markets; During COVID-19, almost $90 \%$ shopped in supermarkets. As for the public spaces' usage, most respondents stayed home, while about $62 \%$ of the ones who went out used the city walkways, and $26.5 \%$ went out along the City Corniche. The public spaces usage rates during COVID19 decreased by $74.4 \%$ of respondents and increased by $18.6 \%$.

In conclusion, Hurghada included custom procedures given its coastal and tourism status. Its residents preserved social distancing according to the online survey while making use of the developed public spaces based on the field observations.

\section{Amman, Jordan}

Amman, the capital of Jordan has a population of about 4 million residents (Population Stat, 2020) living on an area of $799.93 \mathrm{~km} 2$ (Municipality of Greater Amman, 2020). The city of Amman is known to be divided into East and West, there is no clear-cut border between them, yet it is known that the Abdoun corridor and Al-Urdon Street are where the conditions of the built environment change. East Amman is known to be the affordable part of the city compared to the western part of it; facilities and services are not of the same high quality they are in West Amman, but they do exist in the east (Khalifa and Krysiek, 2019). Figures 20 and 21 show the differences in the built environment between the East and West of Amman.

The observations in this case study focus on the Western side of the city, in specific AlRabiyeh and Umm Uthainah neighbourhoods, both of which lie in the heart of West Amman. Due to the restrictions in movement and lockdown during the time of research, Al-Rabieyh and Umm Uthainah were easily accessible to the researcher. While the questionnaire had participants from different parts of the city; East and West. The first case of COVID-19 was recorded in Amman on 2 March 2020. The situation continued to be contained up until I5 March 2020 when the country recorded 12 new cases for people entering the country and people who were in touch with them. Those new cases resulted in a precautionary governmental decision to suspend all departing and arriving flights to Jordan aiming to prevent the spread of the virus (Roya News, 2020a). 


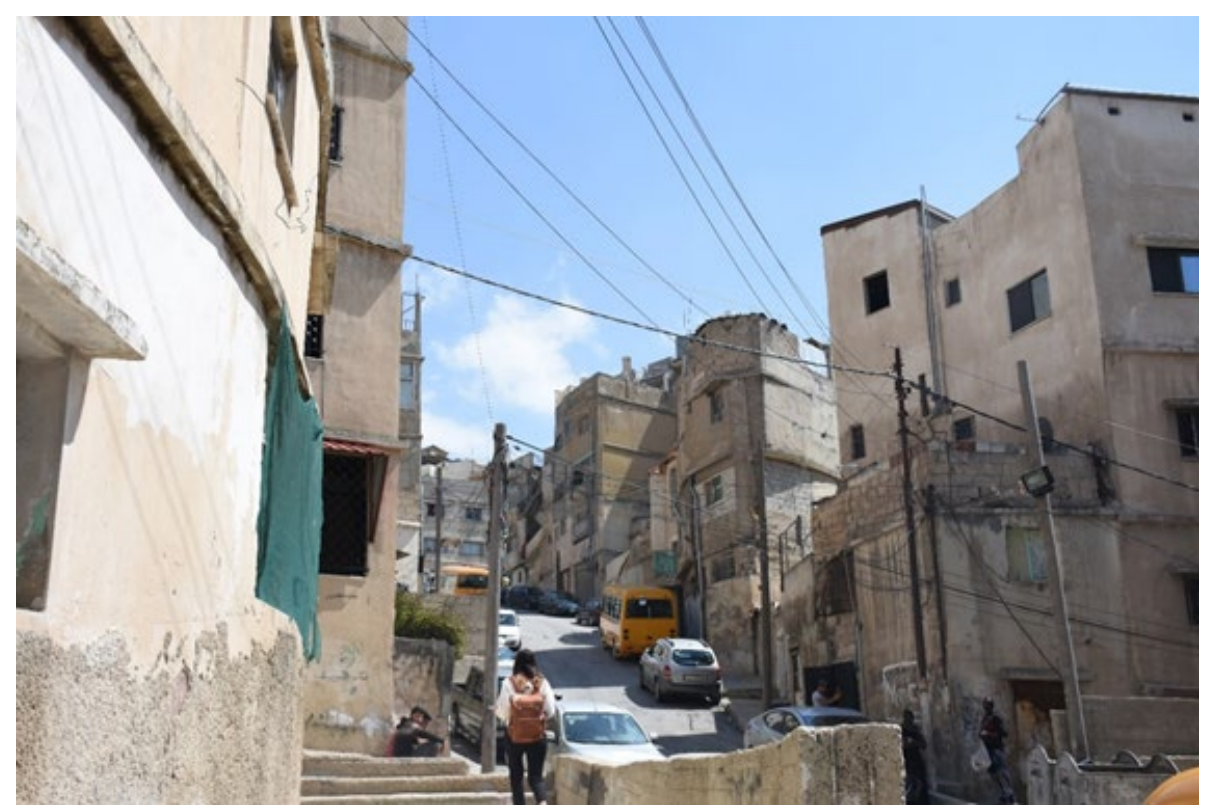

Figure 20. The buildings of Jabal Al-Natheef in East Amman in a deteriorated shape (source: Nowar, 13 April 2019).

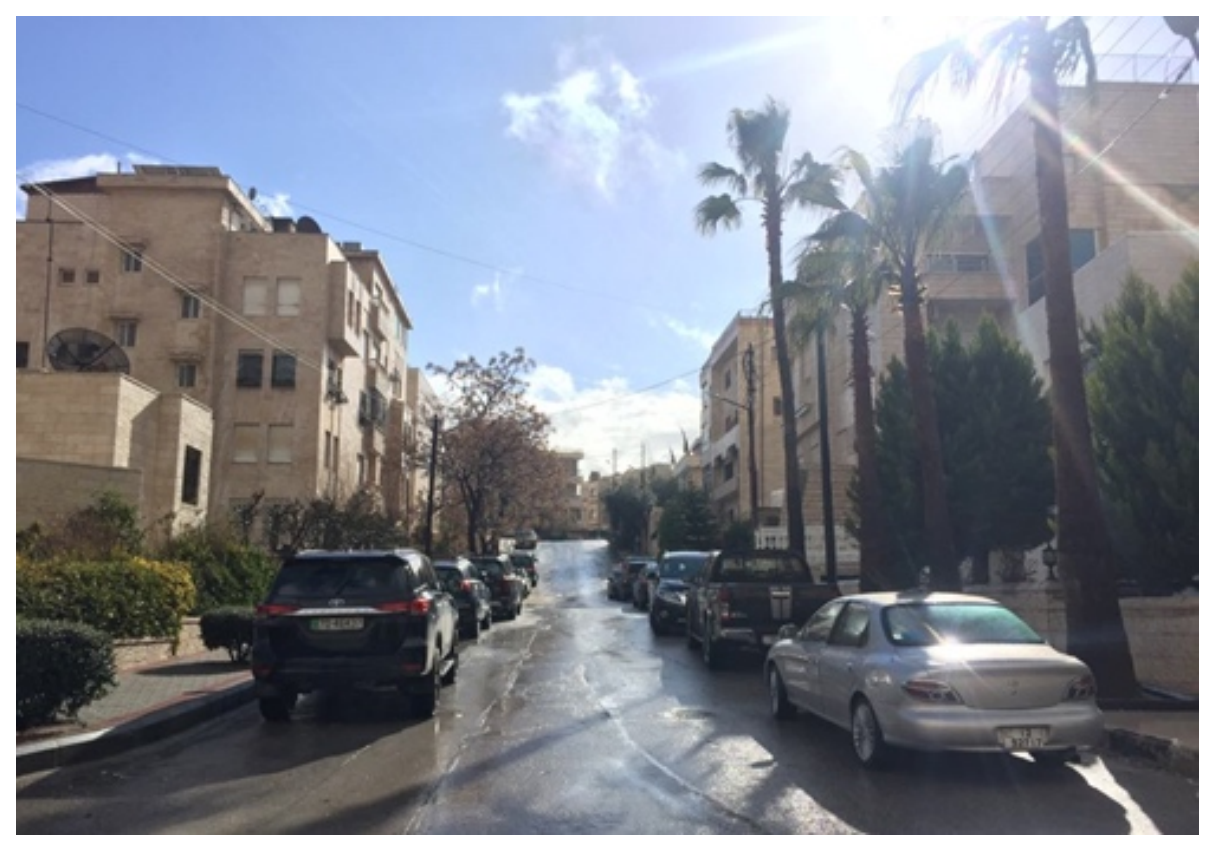

Figure 2I. Wider and streets and newer buildings in Al-Rabyieh in West Amman (source: Nowar, 18 April 2019).

As the cases started to increase slightly, the government announced a nationwide comprehensive curfew in Jordan that started on 21 March 2020 at 7:00 a.m. The curfew prohibited the movement of people whether it was using cars or on foot, as well as the closure of all shops and businesses. It also included the suspension of educational institutes, prayers in mosques and churches, sports activities, and movement between governorates. Any violation of the curfew orders results in paying fines, but the 
punishment could go up to imprisoning the person for up to a year. Air raid sirens went on at 7:00 a.m. announcing the start of the curfew (Aljazeera, 2020). This complete lockdown lasted for four days. Before lifting the comprehensive curfew, the government initiated the delivery of bread and basic grocery to resident's doorsteps using public transportation buses on 24 March 2020. This method was efficient and successful in some neighbourhoods, while it failed in other neighbourhoods. Therefore, on the 25th of March, the curfew was partially lifted, allowing residents to shop for essential items from nearby markets from 10:00 a.m. to 6:00 p.m. Small to medium markets were open along with bakeries, while hypermarkets remained closed. Citizens could move on foot, while public transportation and taxis remained not functioning, and the use of cars was still prohibited. This partial curfew went on for nine days up until 3 April (Middle East Monitor, 2020). Those strict measurements controlled the use of public space, yet in a way, they motivated citizens to maximize the use of the public space -in this case, the streets- within the set limitations. Citizens started slowly reclaiming the streets in their neighbourhoods.

From the 3 April, the government alternated between a comprehensive curfew on weekends (Friday and Saturday) and a partial curfew (permitting pedestrian movement from 10:00 am to 6:00 pm) on weekdays (ibid.). During this period and as a result of those drastic governmental measures, Amman did not only practice social distancing, but it also witnessed an immense change in the socio-spatial behaviour of its residents; people were not only using streets to walk to their destinations -grocery shops- but they were also walking to be active. A resident living in Shmeisani expressed "now we feel that the streets are ours finally" (female, 50s). Families and individuals were seen going for long walks, streets that were once filled with cars are now filled with people either walking, riding bicycles, skateboards, and scooters. According to the questionnaire that included participants living in different areas in Amman, only $7 \%$ of the 70 participants used to walk, and none of them cycled as a means of transportation before the pandemic. On the other hand, $51 \%$ started walking and $4 \%$ started cycling to get to their destinations during the pandemic, while $47 \%$ of them picked up the habit of walking or running as physical activity. This immense increase in numbers indicates the willingness and need for public space.

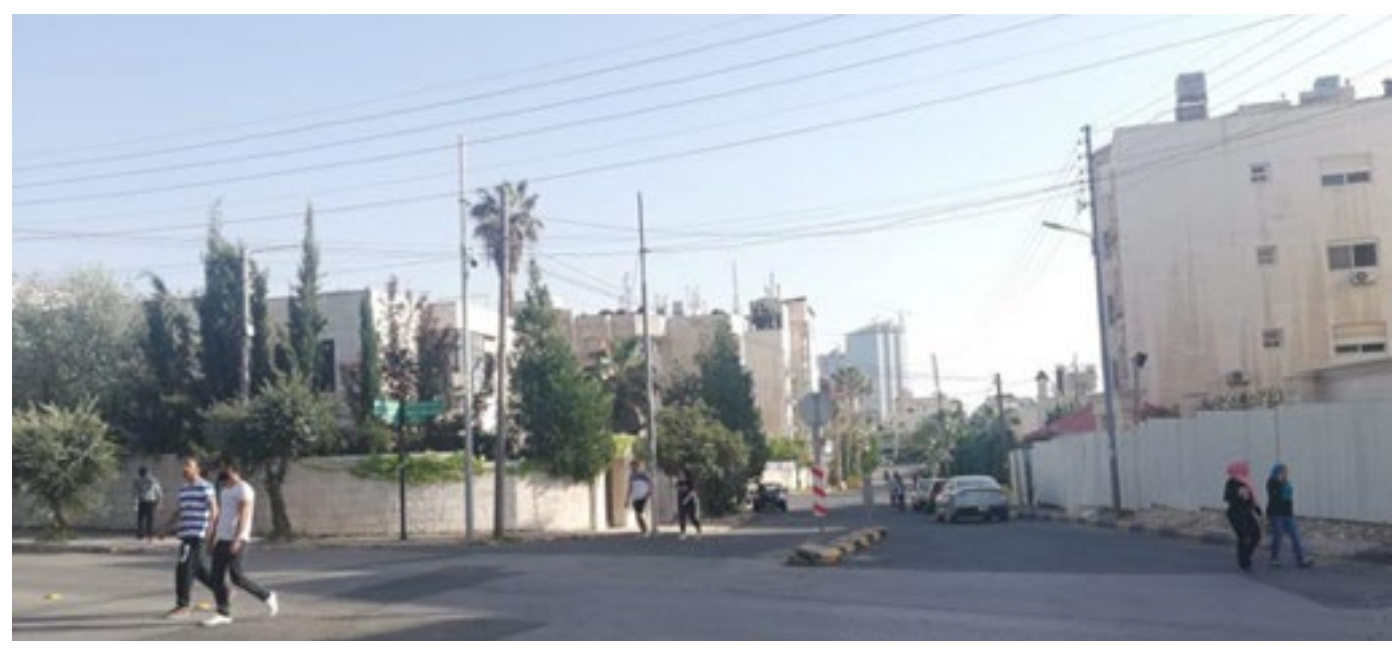

Figure 22. Residents in Amman taking up walking as a daily activity (source: Nowar, 2 May 2020). 
Bicycles were relatively heavily present in the streets, even though the hilly nature of Amman does not make the city bicycle-friendly. A resident living in Dabouq used his bicycle to go to Al-Rabyieh to run an errand, the $10 \mathrm{~km}$ travel distance took him about 40 minutes to reach his destination due to the various hills that came his way. "During my trip, I have witnessed at least 40 bicycles on the streets, and that is impressive for a city like Amman" (male, 30s).

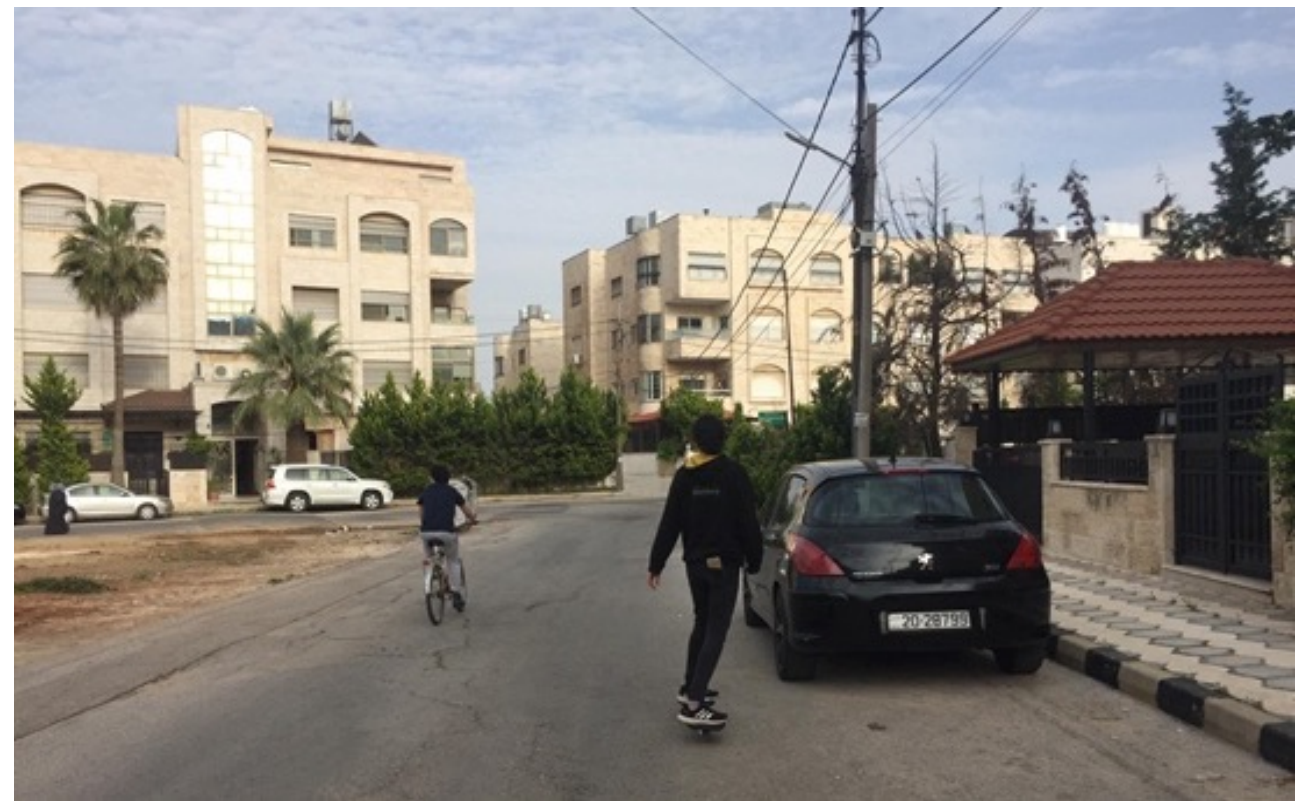

Figure 23. Residents in Amman using bicycles and skateboards in public space (source: Nowar, 21 April 2020).

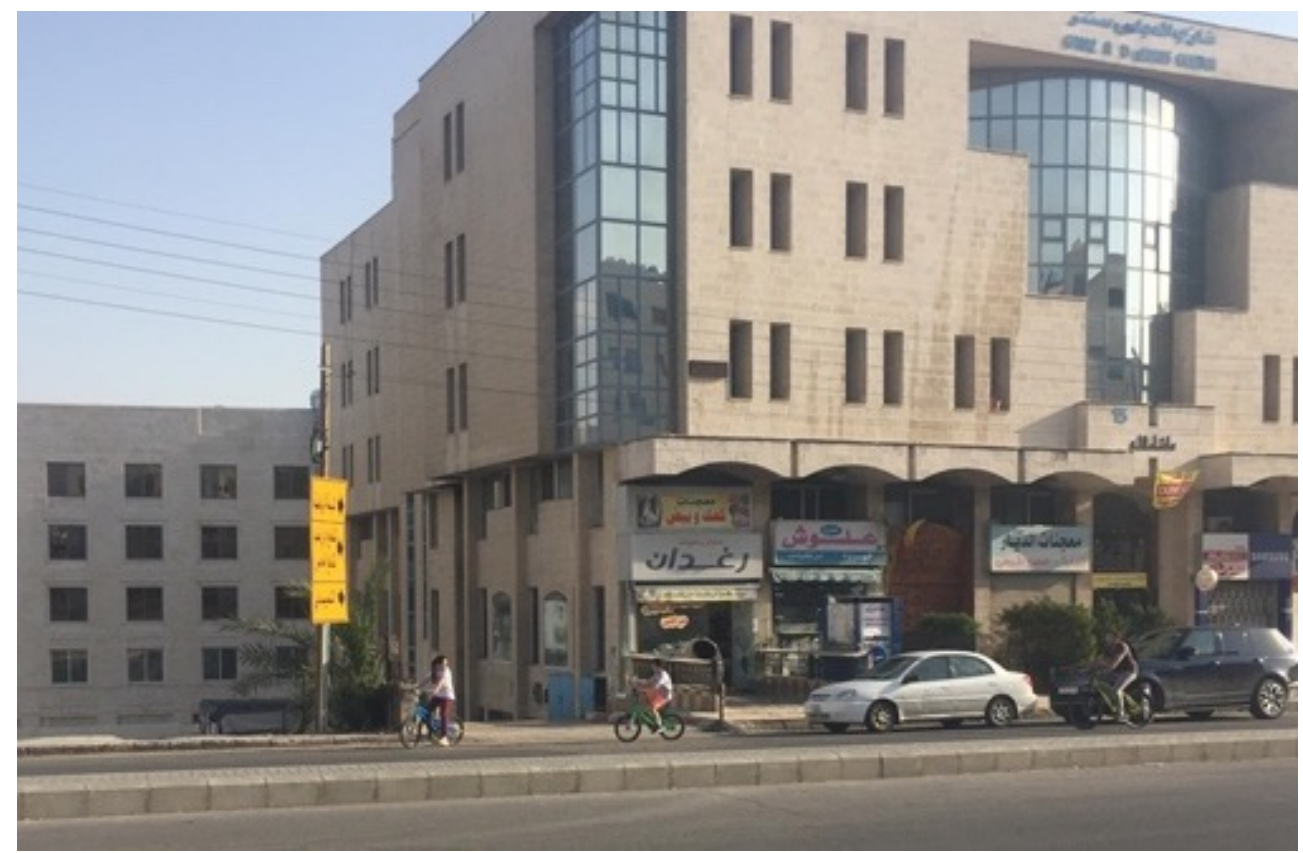

Figure 24. The use of bicycles on the streets of Amman increased (source: Nowar, 20 April 2020). 
The demand for bicycles has increased during the lockdown; it has been noticed through the number of people inquiring about bicycle shops to buy or rent on different social media platforms, below shows some examples from different Facebook groups.
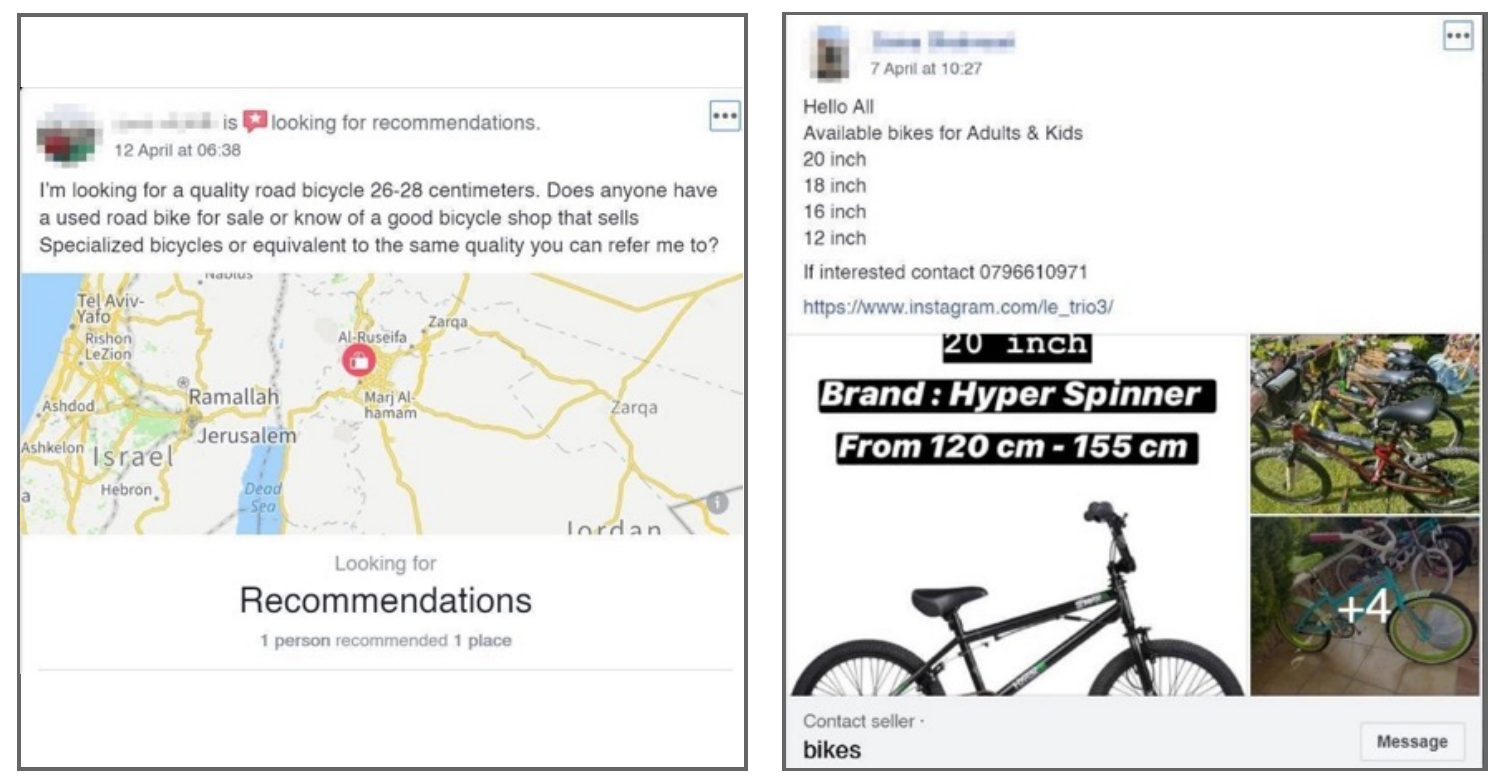

Figure 25. Bicycle demand increased during the curfew in Amman (source: Expats in Amman Facebook group, 2020).

$40 \%$ of the respondents stated that during the pandemic they started using nearby open spaces to their homes; which in this case are represented by the streets of their neighbourhoods -as public parks remained shut until I July 2020. This percent is remarkable when comparing it to the situation before COVID-19, where residents usually preferred to drive to certain areas to walk or sit outdoors; people started reclaiming their surrounding public space as they realized its importance when vehicle movement was prohibited. Starting 29 April 2020, the government allowed vehicle movement from 08:00 a.m. to 06:00 p.m. according to their license plate; alternating between odd and even license plates daily, and a full lockdown of Friday (Roya News, $2020 \mathrm{~b}$ ). As the number of cases was decreasing and the situation in the country stabilized, the government lifted the curfew until midnight allowing all vehicles to move every day including Fridays on 6 June (Grada World, 2020). As the measures and restrictions started to ease up, the number of pedestrians and cyclists decreased in the streets of Amman, yet not to the point, it was before the pandemic. a resident who started using public space during the pandemic expressed that "the measures and regulations set during COVID- 19 reminded us that we can and should use the public space in our city, it is our right" (female, 50s). The pie chart below illustrates the behaviour of residents towards public space. 


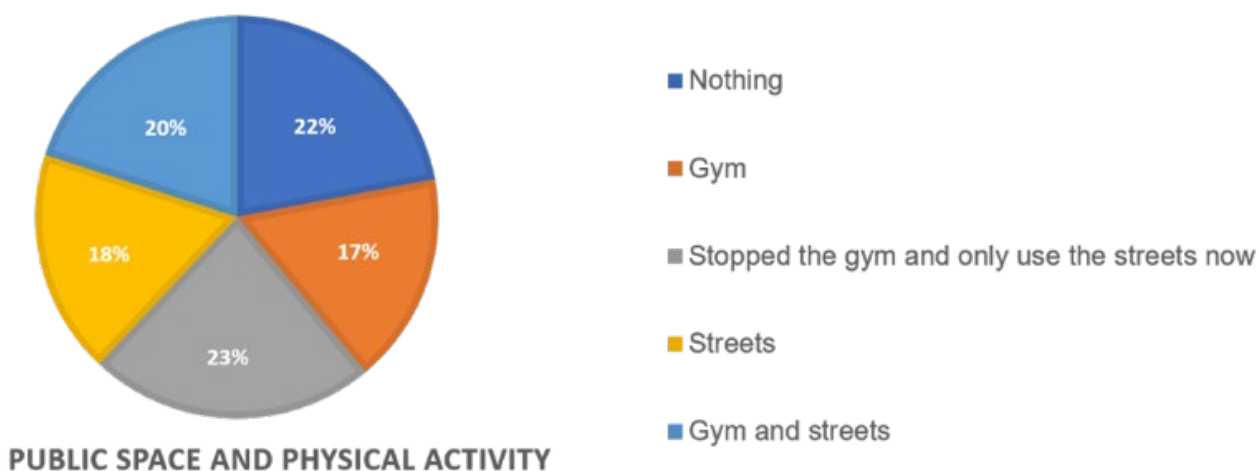

Figure 26. Public space and physical activity chart. (source: Nowar, 2020).

On the other hand, some negative behaviours have been observed in public spaces; such as the littering of gloves and facemask in the streets. Nonetheless, this phenomenon has encouraged a sense of awareness and belonging by some residents which drove them to initiate campaigns that aim to protect the built environment and public space. "DeLitter" campaign is one example; the founder of this initiative, Nerissa Abu Hanna started by collecting the COVID- 19 related waste during her daily walks, this motivated her to start this initiative and invite people to join across the country, each operating in their neighbourhood to collect those plastic gloves and facemasks (The 8 Log, 2020).
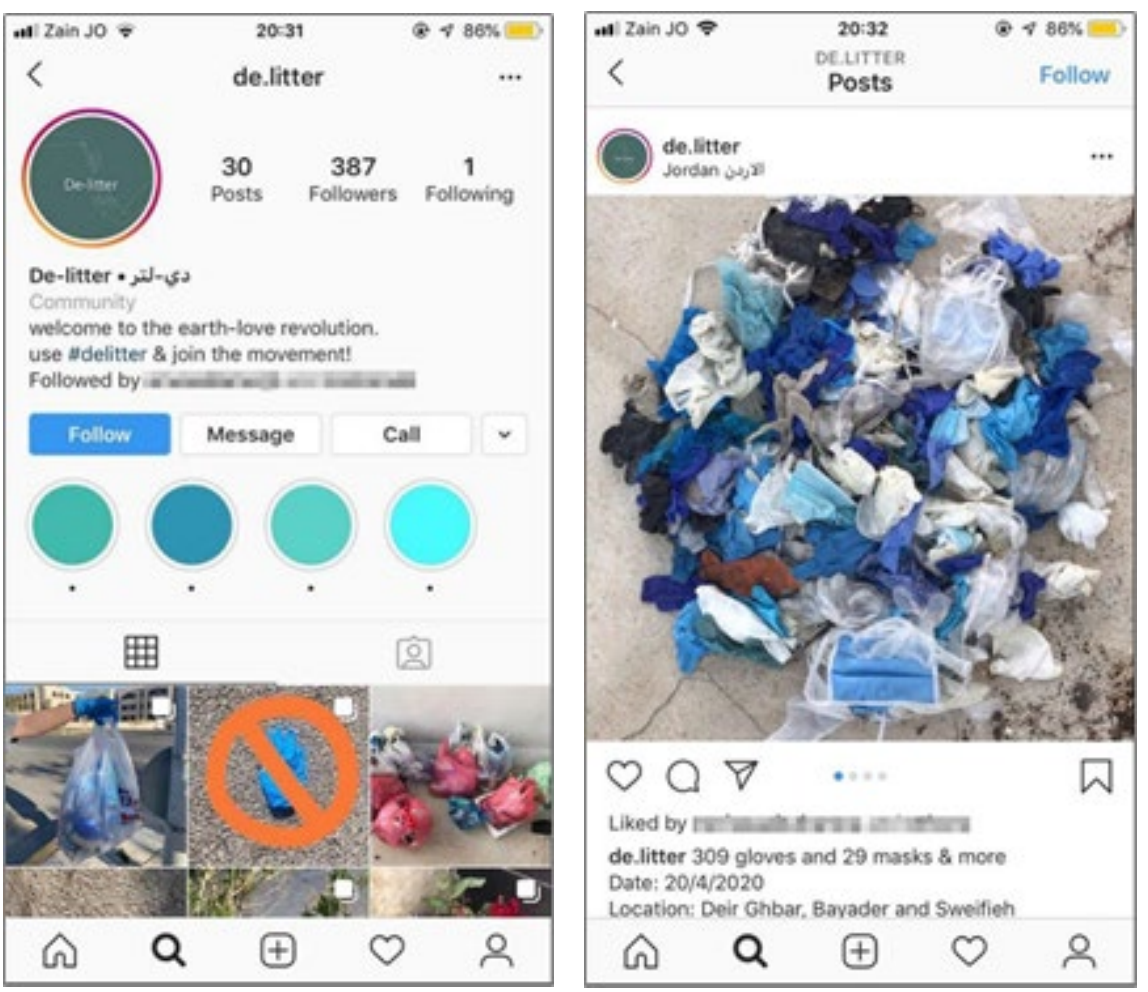

Figure 27. De-Litter page on Instagram as a movement concerned with public space (source: De-Litter Instagram page, 2020). 
The awareness and sense of belonging to the public space have shifted; more people are joining this campaign, organizing, and communicating through its different social media platforms. The figures below show the campaign's Instagram profile, as well as an example of the waste collected on a two-hour walk.

It can be concluded that the measurements set by the government as a result of COVID-19 had a positive impact on the act of reclaiming public space. The culture of public space has witnessed an immense change during the lockdown; residents started using the streets to walk, cycle, and do sports. Many walked to their destinations, even when vehicle movement was allowed again, and the sense of belonging to the public space has increased which can be visibly observed through the cleaning campaigns that took place. This is a turning point for a city like Amman, that is lacking the culture of public space.

\section{Berlin, Germany}

Berlin, the capital of Germany with a population of about 3.6 million, living in an area of $891 \mathrm{~km}^{2}$ with a density of $4,1 \mathrm{I} / 8 \mathrm{~km}^{2}$ (City population, 2020). Berlin has 12 diverse districts; each district has its characteristics. The districts are still categorized based on their location; east and west, while the centre of Berlin is referred to as Mitte (Porter, 2019). The focus of this study is a street called "Sonnenallee" in Neukölln district, as it is one of the hotspots of the pandemic in Berlin and a high percentage of its residents are Arabs. Sonnenallee is a street known in the past for its Lebanese stores and Shisha cafes. In 2015, the street became more vibrant as a huge influx of Syrian refugees inhabited it (Reuters, 2018).

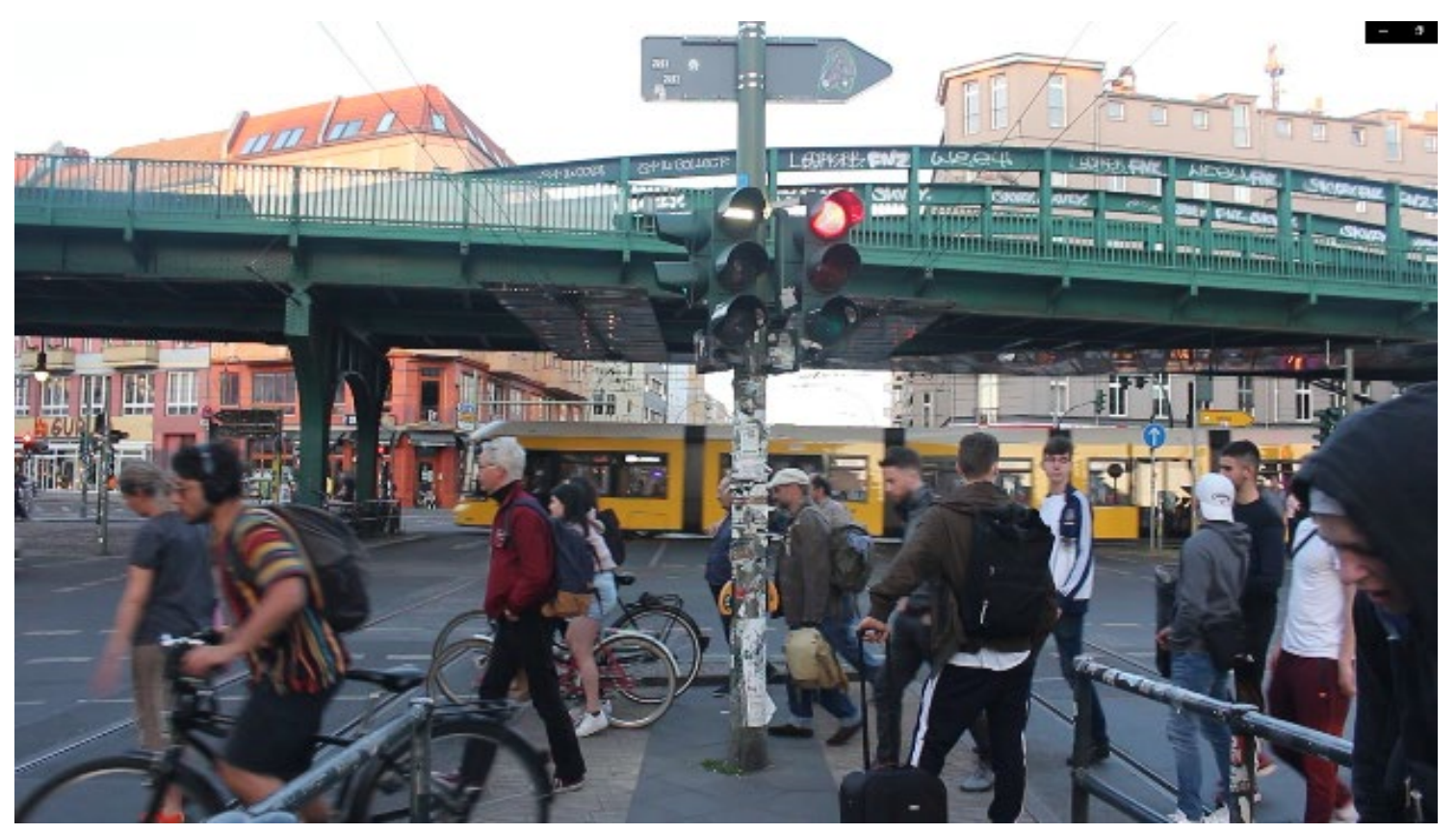

Figure 28. Prenzlauerberg in West Berlin where social distancing is not present (source: Gaballah, I June 2020). 


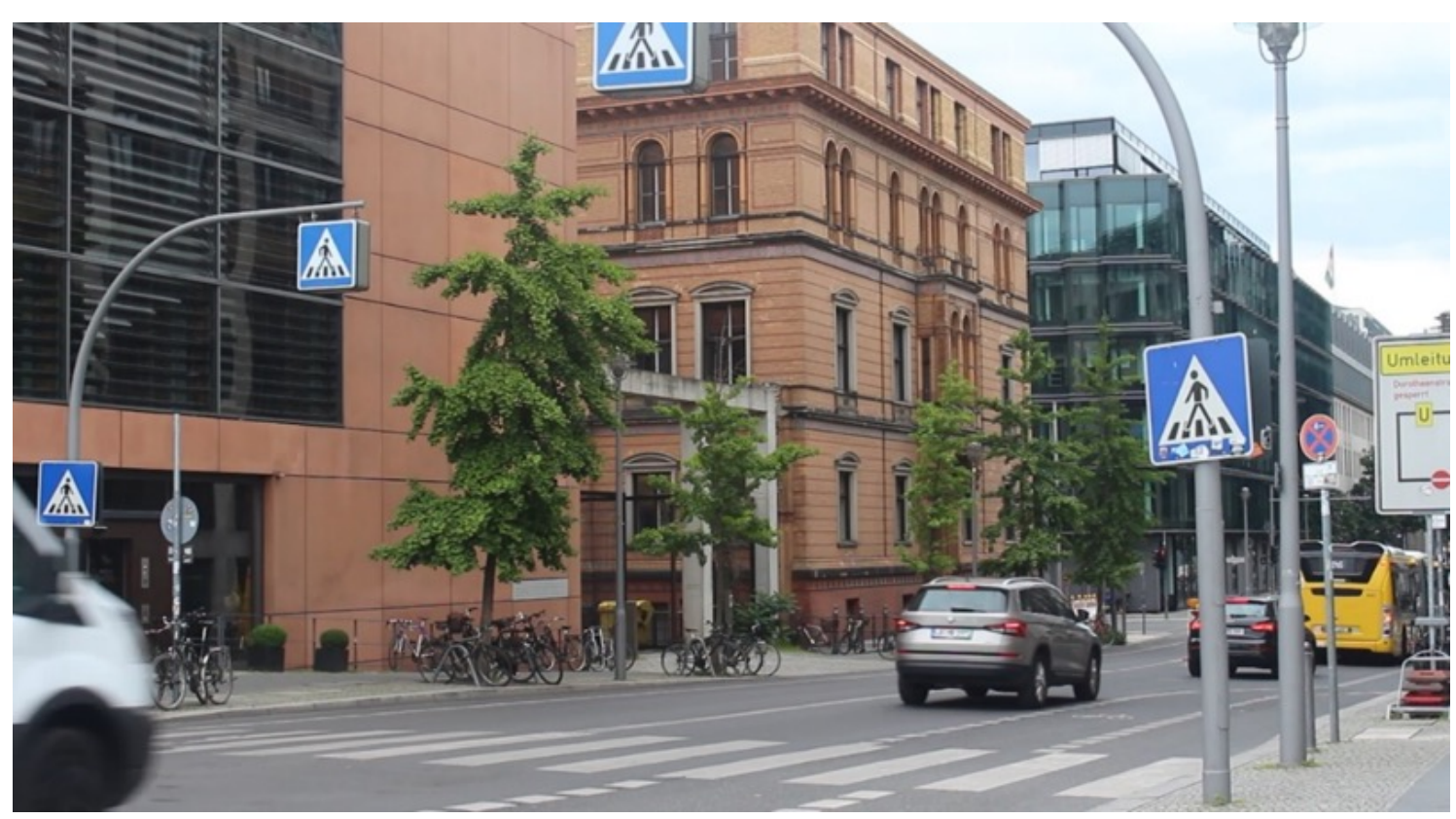

Figure 29. The empty streets of Mitte (source: Gaballah, I June 2020).

On 24 February 2020, German Health Minister Jens Spahn announced the arrival of COVID-19 to Germany, yet not in Berlin. The first case identified in Berlin was on 2 March, while the total number of cases in Germany was I50 cases. In many regions, supermarket shelves were empty because of the high demand and the fear of the pandemic. During the third week of March, Berlin's Universities postponed the upcoming semester, the clubs and bars were forced to close, events with 50 or more people were forbidden and many businesses were forced to close, as well as the opera and concert halls. Berlin and different states came up with different measures to slow down the spread. Nonetheless, on 16 March, the Robert Koch Institute ${ }^{3}$ (RKI) increased the health risk level for people in Germany from moderate to high. Berlin's city centre was very quiet, yet hundreds of Berliners met at parks in the afternoons. During the last 10 days of April and the first week of May, certain types and sizes of shops were opened; the schools, playgrounds, and museums reopened. On 23 April, additional COVID-19 aid packages worth billions of Euros to help employees, people who lost their jobs, mid-sized and small companies, students, and schools. On I5 May, the German government released the COVID- 19 mobile application which alerts users when they have been in contact with persons infected. However, the residents were not pleased with the measurements set by the government that restricted their movement and life. They started staking actions to reclaim their public spaces and the culture of public space that is the essence of life in Berlin. Therefore, on 9 May thousands of Germans demonstrated against those measurements in the capital (DW, 2020); which resulted in a month after the reopening of pubs, fitness centres, ballet schools, casinos, gambling halls, churches, mosques, and synagogues within certain regulations, as well as protests with an unlimited number of people were legal again

\footnotetext{
${ }^{3}$ The German official institute responsible for the health of German citizens.
} 
with strict rules. European Union (EU) and Schengen countries opened their borders for EU citizens and residence permit holders with some exceptions.

Berlin developed a traffic light system for COVID- 19 encompassing three numbers to assess the situation of the pandemic, and based on the traffic light the regulations were set either to be relaxed or strict. Those regulations included; basic obligations, protection and hygiene regulations, the maximum number of persons and bans, quarantine measures, final provisions, and general instructions on the schedule of fines. Regulations regarding socio-spatial behaviours included the minimum distance between people in a public space, the use of masks in public transportation, the measures regarding events, and outdoor activities. Starting August events will be allowed to have up to 500 people, and by September the number will go up to 750 . That lead to an increase in using public open spaces, it had been observed that people in the city preferred to open public spaces over closed ones during those times.

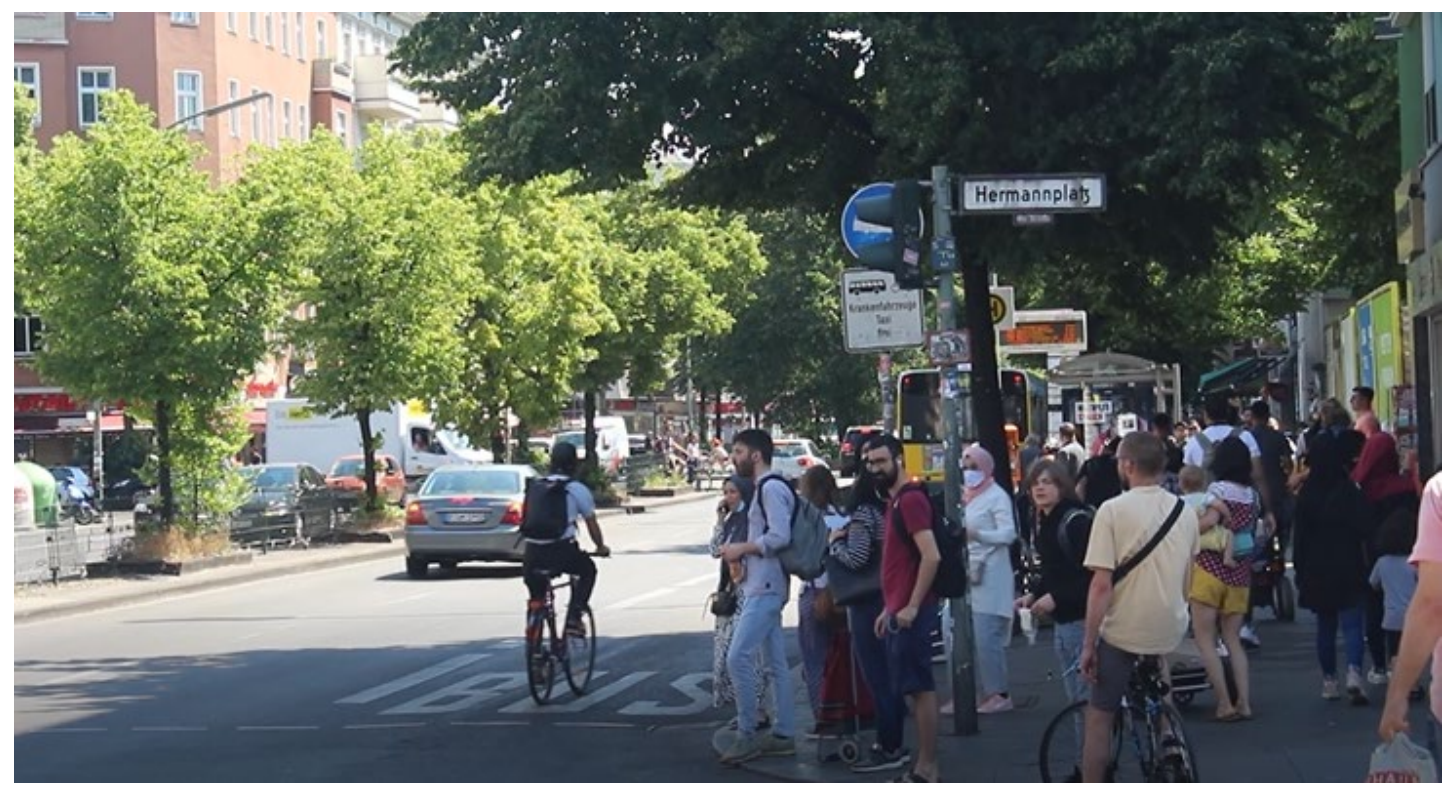

Figure 3I. Streets in Neukölln filled with pedestrians and bicycles (source: Gaballah, 2 June 2020).

The use of bicycles as a means of transportation during the time of the pandemic has immensely increased, residents found it more convenient to use their bicycles than the public transportation system in the city, a participant explained; "it is a hassle to use the transportation system in the city now with the new regulations, it is easier and safer to use my bicycle". As a response to that the state of Berlin started developing new bicycle infrastructure around the city as the need for that was vital (Benecke, 2020). Even though the culture of public space in Berlin exists for a long time; the importance of public space in the city has increased, residents have relied on them more than before. $56 \%$ of the participants claimed that their usage of public space in Neukölln has increased; $37.5 \%$ of them use public space 3-4 times per week. The use of bicycles in this part of the city followed the trend in the city as a whole as well; $71.8 \%$ of participants started using the bicycles solely during the pandemic. However, based on the observation, social distancing seems to be not considered in Sonnenallee (Arabs street), on one hand, due to the nature of the shopping street and its high density during the day, on the other hand, due to high level of social bonding and intimacy in 
the Arab culture, mainly between relatives and friends, which requires direct body contact (e.g., hugging and kissing for greeting each other) (Al-Nasser, 1993). This was reflected later (in October 2020) on the high number of COVID-19 cases to be the highest in Berlin.

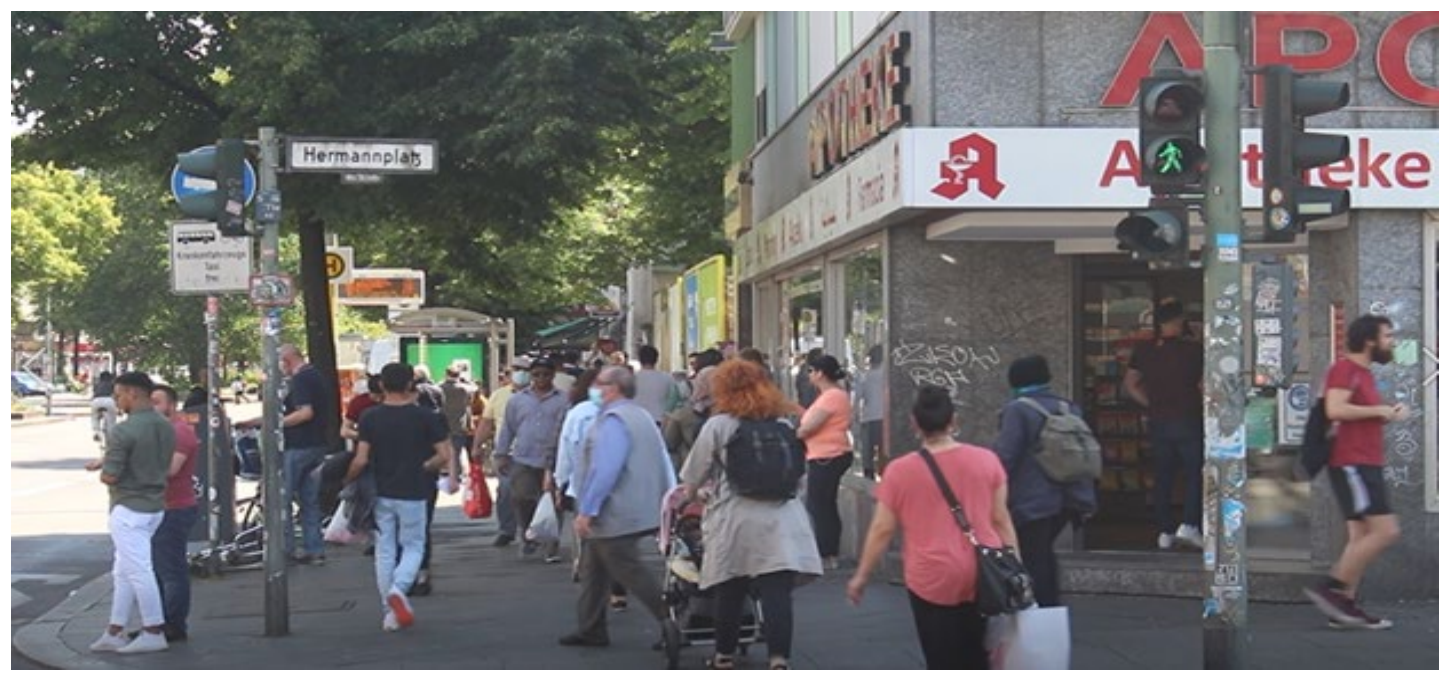

Figure 33. Pedestrians in Neukölln not following the social distancing (source: Gaballah, 2 June 2020).

In a city like Berlin, where residents are already aware of the importance of public space, reclaiming it was evident. The use of public spaces during the pandemic increased due to the minimum recreational options available at certain times. This indicates the importance of maintaining suitable public spaces in the city as well as providing sufficient bicycle lanes, which the state already recognized.

\section{Discussion of Findings: Comparative Analysis}

The results of the study indicate that the large range of the activities occurring in the public space are necessary activities, according to Gehl (2010), despite the fact of the poor and unfavourable condition of the cities' public spaces (New Cairo, Mansoura, and Amman) that does not provide adequate opportunities for social and optional activities. The study shows that the residents of the five studied cities have reclaimed their public space in their own ways during the pandemic. It was noticed that in the cases of $\mathrm{New}$ Cairo, Mansoura, and Amman, the regulations were a turning point to change how residents perceive and use their public space; people started doing sports in the streets, walking to their destinations instead of using the car, their awareness towards the environment and public space have increased, as they were eager to use it. Hurghada has also witnessed the same behaviour from its residents, yet those behaviours in reclaiming public space are not particularly new to the city due to the touristic nature of the city that might have helped in creating the culture of using public space, residents have been using them before the pandemic and continued to do so during the pandemic, in accordance to the governmental regulations. Avoiding crowded spaces (e.g. street markets) was not possible as shown in the cases of Mansoura and Berlin due to the fact of prices affordability that matches certain economic categories of residents. 
The study shows that in Berlin, the cultural background of Arabs has not formed an obstacle for them to follow the regulations set by the government, except for the big gatherings and the social distancing due to the cultural social norms.

In the case of Berlin, using the public space was present as a part of the culture before the pandemic, and the infrastructure is well prepared. However, the use of public spaces by Arab residents (such as parks) has increased, but what was immensely noticeable is the increase in the number of cyclists in the city, people relied more on bicycles than public transportation to avoid crowded buses and underground. The local government of Berlin was very responsive to the behaviour of the residents, as they started establishing new bicycle lanes and widening some of the existing ones, temporarily turned some streets for pedestrians only as a response to the heavy pedestrian traffic in some areas. These governmental reactions and responses towards the residents' behaviour are lacking in the case of Egypt and Jordan. In Amman and New Cairo, some negative behaviours were observed, throwing the waste masks and gloves. The availability of data varied from one studied city to another, which could have had an impact on the residents' behaviour in public space. This was clear in Berlin's case when the residents were well informed about the number of cases and their locations, they were cautious to use those spaces, even if the government did not quarantine and temporarily close those areas. The German government collaborated with Esri, Robert Koch Institute, and the Institute for Hygiene and Public Health at the University of Bonn to create an online platform to follow up with the new cases all over Germany in general to the level of districts and making the information available and accessible for all residents. In addition to launching a mobile application to track and inform the residents on active cases. The same thing happened in Amman, where the government alongside the Ministry of Health launched a website and a mobile application to keep the citizens informed. Yet, this has not been so effective in the Egyptian case, although the government has launched an app to track the COVID-I 9 but was not used by the majority.

\section{Conclusion and Recommendations}

Governments have experienced immense pressure dealing with COVID-19 and they still are, yet each city has dealt with COVID-19 differently; different measures were implemented in each of the studied cities, they have also been changing with time depending on the severity of the situation, availability of data, the capacity of its health facilities, population density, and people's culture. Therefore, some governments were more responsive adapting to the rapidly changing situation than others. On the other hand, people in different cities have responded differently to those measures depending on those factors as well.

Nonetheless, residents in all studied cities - whether they were in the MENA region or Europe- were immensely connected to their public space regardless of the condition of those spaces and the level of preparedness and response of the governments towards public space. New patterns of behaviour have emerged. Unfortunately, those behaviours were not only limited to positive ones; as some of the studied cities have also witnessed a new type of waste being littered in public spaces, but gloves and masks also were not discarded properly, they were filling the streets in some areas of some of the cites. This needs more attention from governments to raise the citizens' awareness. 
On the other hand, governments - especially on the local level - have to be more aware and responsive to the change in the residents' behaviour, and accordingly, take decisions supported by urban designers, such as constructing new bicycle lanes, and giving the priority to pedestrians over vehicular movement. In the time of the COVID-19 pandemic, public space becomes even more crucial for citizens - as shown in the studied cities. This raises the question: To what extent our streets are well designed to be efficient public spaces? and is this going to continue and develop into an urban planning process for resilience? Consequently, the paper highlights the importance of co-producing and co-designing public space, especially in such times.

Hence, the paper recommends a collaborative framework, and an integrated approach in designing public spaces, that includes the local community in cooperation with urban planners and governments; as a lesson learned from Berlin's case, where the government listened to the needs of the citizens and responded accordingly. On the other hand, the city dwellers' adaptation is a promising start in reclaiming their public spaces; as governmental measures (New Cairo, Mansoura, Hurghada, \& Amman) stimulated a drastic change in cities where the use of public spaces used to be minimal. More interdisciplinary studies are needed between several disciplines: urban planning, political sociology, environmental psychology, behavioural studies, public policy, cultural anthropology, and public health. This would help to reach a better understanding of the relationship between governments measures and people's behaviour in public space.

\section{References}

Aljazeera (2020) 'Round-the-clock curfew in Jordan to battle COVID-I 9 virus outbreak', Aljazeera, [online]. Available at: https://www.aljazeera.com/news/2020/03/jordan-announcesclock-curfew-COVID- 9virus-outbreak-200320184824472.html (Accessed: 25 July 2020).

Altayry, A. (2020) 'Red Sea resorts and beaches empty on Easter holidays due to COVID-19 virus', Al Ahram Gate, 20 April 2020 [online]. Available at: http://gate.ahram.org.eg/News/2397980.aspx (Accessed: 29 July 2020)

Al-Nasser, A. (1993). 'The Social Function of Greetings in Arabic'. Zeitschrift für Arabische Linguistik, Vol. 26, pp. I5-27. Wiesbaden: Harrassowitz Verlag.

Ayed (Al-Dajah), H.,A., Mubark, M. M., \& Al-Oweimer, W. (20I2) 'Attitudes of the Arab community in relation to cultural identity and social integration in Germany', Canadian Social Science, 8(I), I9I-199.

Aytekin, E. (2020) 'Steps taken by countries in fighting COVID- 19 pandemic', Ankara: Anadolu Agency, [online]. Available at: https://www.aa.com.tr/en/health/steps-taken-by-countries-infighting-COVID-19-pandemic/18I2009 (Accessed: 26 July 2020).

Benecke, M. (2020) 'On your bike! Coronavirus prompts cycling frenzy in Germany', Deutsche Welle, (no date) [online]. Available at: https://www.dw.com/en/on-your-bicycle -COVIDI9virus-prompts-cycling-frenzy-in-germany/a-534620I8 (Accessed: I5 June 2020)

Berlin (2020) Home Page [Online]. Available at: https://www.berlin.de/ (Accessed: 28 July 2020)

Biennale Spazio Publico (2013) The Charter of Public Space [Online]. Available at: http://www.biennalespaziopubblico.it/outputs/the-charter-of-public-space/ (Accessed: 22 July 2020).

Central Agency for Public Mobilization and Statistics. (2020) Home Page [Online]. Available at: https://www.capmas.gov.eg/HomePage.aspx (Accessed: 29 July 2020).

City Population. (2020a) Egypt, Governorates [Online]. Available at: https://www.citypopulation.de/en/egypt/cities/ (Accessed: 19 July 2020). 
City Population. (2020b) Berlin [Online]. Available at: https://www.citypopulation.de/en/germany/berlin/berlin/I 1000000 berlin/?fbclid=IwAR30q g-SN_Ze53q8XtFCY2Y0 DcHkMV-oJva_bnbfliHflge2OOqb9ZbKi8 (Accessed: 29 July 2020).

Dakahlia Governorate. (2020) Cities and towns [Online]. Available at: http://www.dakahliya.gov.eg/SitePages/ctzTasks_CentersandCities.aspx (Accessed: 19 July 2020).

Danisworo (1989). Konsep Peremajaan Kota, Institut Teknologi Bandung.

Deusche Welle (2020) 'Germany: Thousands of protesters slam isolation measures', Deutsche Welle, (9 May) [online]. Available at: https://www.dw.com/en/germany-thousands-ofprotesters-slam-isolation-measures/a-5338289I (Accessed: 29 July 2020).

Egypt Independent (2020) 'Egypt's COVID-19 virus infection rates are expected to reach zero soon: Official', Egypt Independent, [online]. Available at: https://egyptindependent.com/egypts-COVID-19virus-infection-rates-are-expected-toreach-zero-soon-official/ (Accessed: 29 july 2020).

Egyptian Streets (2020a) 'Egypt Lifts Most COVID-I 9 Restrictions, Moves to 'Coexist' With the Virus', Egyptian Streets news, 23 June [online]. Available at: https://egyptianstreets.com/2020/06/23/egypt-lifts-most-COVID-19-restrictions-moves-tocoexist-with-the-virus/ (Accessed: 29 July 2020).

Egyptian Streets (2020b) 'Cairo No Longer the City that Never Sleeps? Early Shopping Closing Hours 'Permanent Decision', Egyptian Streets news, 24 June [online]. Available at: https://egyptianstreets.com/2020/06/24/cairo-no-longer-the-city-that-never-sleeps-earlyshopping-closing-hours-permanent-decision/ (Accessed: 29 July 2020).

Egypt Today (2020) 'Egypt announces first COVID-I 9 virus infection', Egypt Today, I4 February [online]. Available at: https://www.egypttoday.com/Article/l/8164l/Egypt-announces-firstCOVID-I 9virus-infection (Accessed: 29 July 2020).

El Deeb, S. (2020) 'Mansoura residents practice sports on the street after the ban ends to challenge Corona', El Yom El Sabeaa, 9 July [online]. Available at: https://cutt.ly/uQaTGtb (Accessed: 25 July 2020). 
COVID-19 Pandemic: Between Public Space and Users' Behaviours

France 24 Cairo (2020) 'Egypt locks down major Red Sea tourist resorts', France 24, 17 March [online]. Available at: https://www.france24.com/en/202003 I7-egypt-locks-down-major-redsea-tourist-resort (Accessed: 29 July 2020).

Gardaworld (2020) 'The Egyptian regulations during COVID-I 9 pandemic', Garda World, 23 April [online]. Available at: https://www.garda.com/crisis24/news-alerts/335566/egyptgovernment-extends-nighttime-curfew-through-ramadan-april-23-update-16 (Accessed: 29 July 2020).

Gehl, J. (1987). Life between Buildings: Using Public Space, Washington DC: Island Press.

Gehl, J., (2007). 'Public spaces for a changing public life' in Travlou, P., \& Ward Thompson, C. (eds.). Open Space: People Space (Ist ed.). Taylor \& Francis. https://doi.org/l 0.4324/978020396/827, pp.3-II.

Gehl, J. (2010). Cities for People. Washington DC: Island Press.

Geertz, C. (1973). The interpretation of cultures: selected essays. New York: Basic Books.

Gomaa, A. (2020) 'The Ministry of Health reveals the fate of the first case of COVID-19 in Egypt', MSN, [Online]. Available at: https://www.msn.com/ar-eg/news/national/

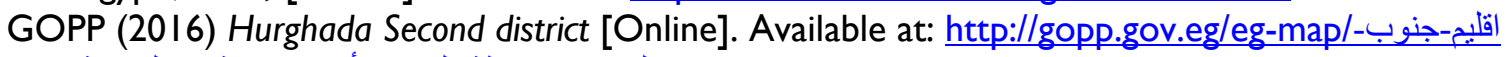
(الصعيد/محافظة_البحر _الأحمر/قسم-ثاني_الغردقة (Accessed: 3 May 2020)

GOPP. (2020) Red Sea Governorate [Online]. Available at: http://gopp.gov.eg/eg-map/قلي-جنوبالصعيد/محافظة_البحر -الأحمر (Accessed: 3 May 2020).

Grada World. (2020) 'Jordan: Authorities to further ease COVID-19 restrictions from June 6 /update 22', Garda World, 5 June [online]. Available at:

https:/www.garda.com/crisis24/news-alerts/34822I/jordan-authorities-to-further-easeCOVID-19-restrictions-from-june-6-update-22 (Accessed: 25 July 2020).

Hatchett, R. J., Mecher, C. E. and Lipsitch, M. (2007) 'Public health interventions and epidemic intensity during the 1918 influenza pandemic', Proceedings of the National Academy of Sciences, volume( I04) [online]. Available at: https://doi.org// 0.1073/pnas.061094II 04 (Accessed: 25 July 2020).

164 | The Journal of Public Space, 6(I), 202I| ISSN 2206-9658

City Space Architecture / UN-Habitat 
Hameda, N. (2020) 'We monitor the continuity of sterilization of the railways and the metro trains to face covid-19', Akhbar Elyoum, 12 May [online]. Available at: https://akhbarelyom.com/news/newdetails (Accessed: 29 July 2020)

Hamzah, F. B., Lau, C., Nazri, H., Ligot, D. V., Lee, G., Tan, C. L., Shaib, M., Zaidon, U. H.B., Abdullah, AB and Chung, M. H. (2020) 'CoronaTracker: worldwide COVID-I 9 outbreak data analysis and prediction', Bull World Health Organ, vol. I, p. 32.

Innes, J. E., \& Booher, D. E. (2000). 'Public Participation in Planning: New Strategies for the 2 Ist Century'. Working Paper. Berkeley, California: University of California, Institute of Urban and Regional Development.

Jacobs, J. (196I). The Death and Life of Great American Cities. New York: Division of Random House.

Johnson, N. P. and Mueller, J. (2002) 'Updating the accounts: global mortality of the 1918-1920: Spanish influenza pandemic' Bulletin of the History of Medicine, volume (76/spring 2002) [online]. Available at: https://muse.jhu.edu/article/4826 (Accessed: 25 July 2020).

Khalifa, H. and Krysiek, P. (2019). 'Wealth and Poverty in Amman', Goethe Institute, (no date) [online]. Available at: http://www.goethe.de/ins/jo/amm/pri/ema/far/wap/enindex.htm. (Accessed: 17 August 2020).

Marcus, I., (2020). "Germany and the COVID-19 virus". Berlin, the Berlin Spectator, 2020. [online]. Available at: berlinspectator.com/2020/07/I I/chronology-germany-and-theCOVID-19 virus-4/. (Accessed: 25 July 2020).

McFarlane, C., \& Robinson, J. (20I2) 'Introduction-Experiments in Comparative Urbanism'. Urban Geography, 33 (6). Comparative Urbanism, pp. 765-773, DOI: 10.2747/0272-3638.33.6.765

Nijman, J., (2007). Introduction-Comparative Urbanism. Urban Geography, 28(I), PP I6, DOI: 10.2747/0272-3638.28.1.I

NUCA (New Urban Communities Authority). (2020) New Cairo [Online]. Available at: http://www.newcities.gov.eg/know_cities/New_Cairo/default.aspx?fbclid=IwAR leFy9vXYN 38z5-8UxwSGbyYMkmKUVuHc2KXtBs)hJEzCp7IVBh273Odlg (Accessed: 20 July 2020)

Raghavan, S. (2020) 'Egypt thought it dodged the worst of the pandemic. But now hospitals are being overwhelmed', The Washington Post, 6 November [online]. Available at: shorturl.at/fDKM0 (Accessed: 6 November 2020). 
COVID-19 Pandemic: Between Public Space and Users' Behaviours

Robinson, J., (2015) 'Comparative Urbanism: New Geographies and Cultures of Theorizing the Urban'. International Journal for Urban and Regional Research, pp. 187-199.

Roya News. (2020a) 'All flights from and to Jordan suspended as of today', Roya News, 17 March [online] Available at: https://en.royanews.tv/news/20266/All-flights-from-and-toJordan-suspended-as-of-today (Accessed: 25 July 2020).

Roya News. (2020b) 'Citizens allowed to use their vehicles as of Wednesday through even-odd license plate policy', Roya News, 27 April [online]. Available at: https://en.royanews.tv/news/2085I/2020-04-27. (Accessed: 25 July 2020).

The 8 Log. (2020) 'Jordanian "De-Litter" Clears Neighborhoods from Discarded Face Masks and Gloves', THE8LOG, 7 May [online]. Available at: https://www.the8log.com/jordanian-delitter-clears-neighborhoods-from-discarded-face-masks-and-gloves/ (Accessed: 25 July 2020).

UNESCO (2020) Inclusion Through Access to Public Space [Online]. Available at: http://www.unesco.org/new/en/social-and-human-sciences/themes/urbandevelopment/migrants-inclusion-in-cities/good-practices/inclusion-through-access-to-publicspacel (Accessed: 25 July 2020).

Wari, S. (2017). Palestinian Berlin: Perceptions and Use of Public Space: Perception and Use of Public Space. Habitat - International: Schriften Zur Internationalen Stadtentwicklung, Band 22. Berlin: Lit Verlag.

WHO. (2020) Archived: WHO Timeline - COVID-19 [Online]. Available at: https://www.who.int/news-room/detail/27-04-2020-who-timeline---COVID-19. (Accessed: 26 July 2020).

Whyte, W. (1985). 'The Social Life of Small Urban Space'. 10(4). Washington DC: the Conservation Foundation.

World Population Review. (2020) Population of Cities in Egypt [Online]. Available at: https://worldpopulationreview.com/countries/egypt-population/cities/ (Accessed: 26 July 2020)

166 | The Journal of Public Space, 6(I), 202I| ISSN 2206-9658

City Space Architecture / UN-Habitat 